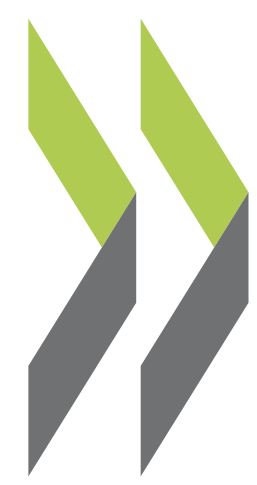

OECD Working Papers on Insurance and Private Pensions No. 1

\title{
Funding Rules and Actuarial Methods
}

\section{Colin Pugh}




\title{
OQECD
}

FUNDING RULES AND ACTUARIAL METHODS

\author{
Colin Pugh
}

October 2006

\section{OECD WORKING PAPER ON INSURANCE AND PRIVATE PENSIONS}

No. 1

Financial Affairs Division, Directorate for Financial and Enterprise Affairs Organisation for Economic Co-operation and Development 2 Rue André Pascal, Paris 75116, France www.oecd.org/daf/fin 


\section{ABSTRACT/RÉSUMÉ}

\section{Funding Rules and Actuarial Methods}

This paper outlines the regulatory framework within which occupational defined benefit pension plans are financed and addresses the challenges facing the funding of such plans. The Appendices include a summary and discussion of the funding regulations in twelve OECD countries plus Brazil - all of which have a long history of DB plans. The paper draws on these experiences in these countries and develops recommendations for the future regulation of pension plan funding in OECD countries and elsewhere.

The paper addresses such central issues as the types of funding and actuarial costing methods that could be considered as best practice. It identifies the challenges facing regulatory authority in establishing appropriate minimum funding requirements and maximum funding limitations. In particular, the paper analyses the different approaches taken by various regulators in light of the problems experienced by plan sponsors since the early years of the $21^{\text {st }}$ century. Finally, the paper addresses the sometimes uneven risk sharing of funding shortfalls and funding excesses (surpluses) between plan sponsors and plan members. All of these issues still are being actively debated, and regulations already are being changed.

JEL codes: $G 18, G 23$, J32

Keywords: regulation; pension fund; defined benefit plan; occupational pension plan; funding requirements; actuarial costing methods.

$* * * * *$

\section{Règles de financement et méthodes actuarielles}

Ce document décrit le cadre réglementaire dans lequel s'insèrent les plans de pensions professionnelles à prestations définies et examine les défis posés par le financement de ces plans. Les appendices sont consacrés à une présentation des règles de financement en vigueur dans 12 pays de l'OCDE plus le Brésil - tous pays qui ont une longue histoire de plans à prestations définies. Le document recense les expériences menées dans ces pays et formule des recommandations en vue de la réglementation du financement des plans de pensions à l'avenir, dans les pays de l'OCDE et dans d'autres pays.

Cette étude traite des questions centrales que sont, par exemple, le type de financement et les méthodes d'évaluation actuarielles que l'on peut considérer comme constituant des pratiques optimales. Il identifie les défis auxquels se trouvent confrontées les instances de réglementation lorsqu'il s'agit de définir des exigences de financement minimales et, à l'inverse, des plafonds de financement. En particulier, il analyse les différences d'approche des régulateurs face aux problèmes qu'ont rencontrés les promoteurs de plans, au tout début du $21^{\text {eme }}$ siècle. Enfin, le document traite du partage des risques, parfois inégal, entre les promoteurs du plan et les membres du plan en cas de déficit de financement et, à l'inverse, d'excédent de financement (sur-capitalisation). Toutes ces questions sont activement débattues et les réglementations sont déjà en cours de révision.

Classification JEL : G18, G23, J32

Mots clés: réglementation; fond de pension; plans à prestations définies; plans de pensions professionnelles; règles de financement; méthodes d'évaluation actuarielles. 
OECD Working Paper on Insurance and Private Pensions

\section{Copyright OECD, 2006}

Applications for permission to reproduce or translate all, or part of, this material should be made to: Head of Publications Service, OECD, 2 rue André-Pascal, 75775 Paris Cédex 16, France. 


\section{TABLE OF CONTENTS}

\section{FUNDING RULES AND ACTUARIAL METHODS}

SECTION 1: Introduction 4

SECTION 2: Historical Development Of Funding Regulations ................................................ 6

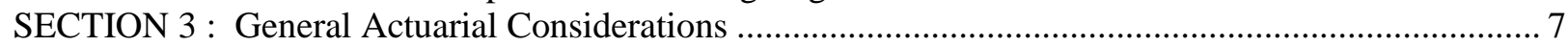

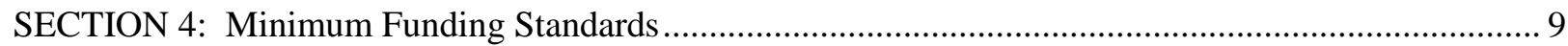

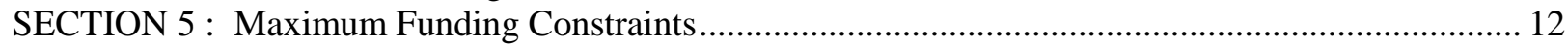

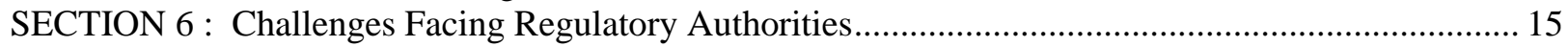

SECTION 7: Recent Trends And Developments............................................................................. 19

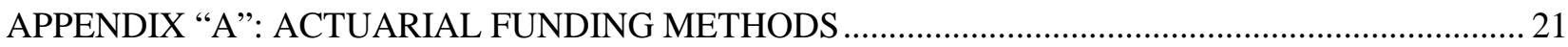

APPENDIX "B”: PENSION PLAN FUNDING REGULATIONS .......................................................... 25

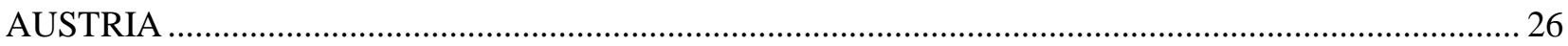

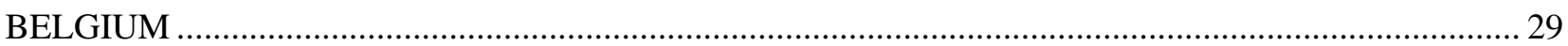

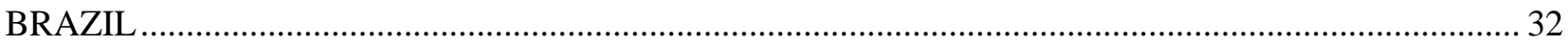

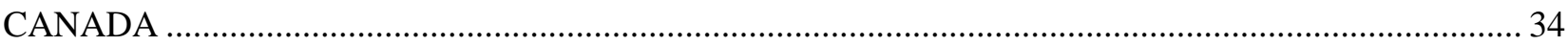

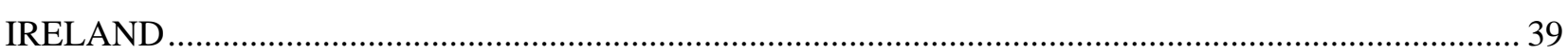

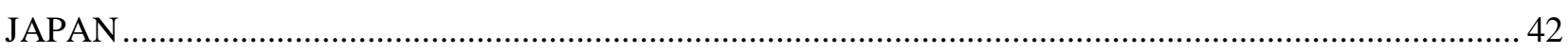

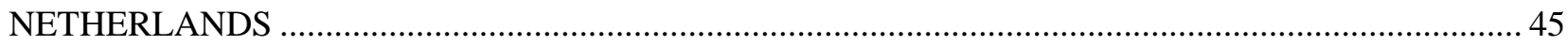

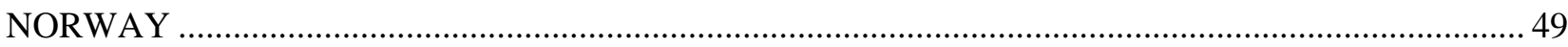

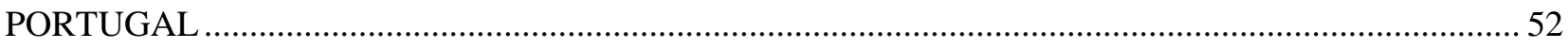

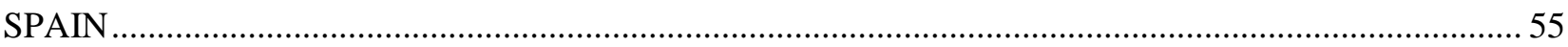

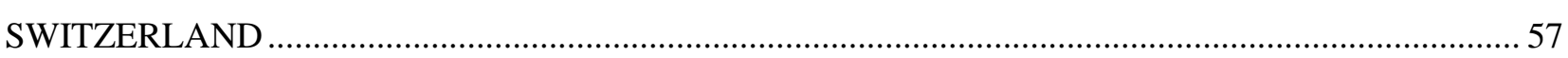

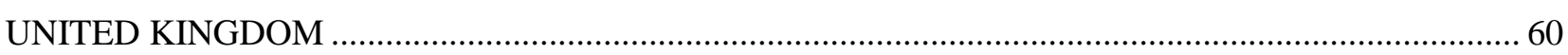

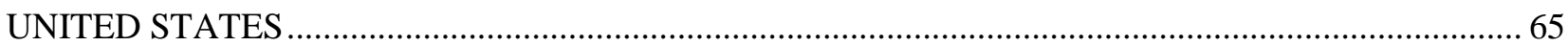




\title{
FUNDING RULES AND ACTUARIAL METHODS
}

\author{
C. Pugh ${ }^{1}$
}

\section{SECTION 1: INTRODUCTION}

\section{Basic Objectives of this Report}

1. This report outlines the regulatory framework within which defined benefit (DB) pension plans are financed and addresses the challenges facing the funding of such plans. The Appendices include a summary and discussion of the funding regulations in selected OECD countries, most of which have a long history of externally funded DB pension plans. This report attempts to draw on the positive and negative experiences in these countries and then develop ideas and recommendations for the regulation of pension plan financing in OECD countries and elsewhere. This paper will address such central issues as:

- What funding and actuarial costing methods may be considered as best practice? In particular, should the projected unit credit method be the universal norm? How desirable is consistency with accounting principles?

- What are the pros and cons of imposing minimum and maximum funding requirements? How much flexibility should companies have to adjust their funding levels to meet these requirements?

- Should regulators establish a precise set of actuarial assumptions (economic and demographic) to be used in actuarial valuations? Alternatively, how much flexibility should actuaries have in setting assumptions?

\section{We live in difficult times.}

2. The first version of this report was written in 2003, following a three-year period during which the funded positions of defined benefit pension plans deteriorated rapidly. Some governmental authorities reacted by creating yet another layer of regulations to protect the current funding position of DB plans. Other countries concluded that these were not normal times and that a temporary relaxation of funding rules would better serve the overall economy and the longer term interests of the various stakeholders. Although pension fund assets have performed relatively well since 2002, a large percentage of defined benefit pension plans continue to be underfunded. The situation has been aggravated particularly by abnormal increases in plan liabilities resulting from declining interest rates and increased pensioner

\footnotetext{
${ }^{1}$ The author would like to thank Fiona Stewart and Juan Yermo from the OECD, and the governmental Delegates to the OECD Working Party on Private Pensions, for their valuable comments and assistance. I would also like to thank the OECD both for proposing the idea of this study and for its subsequent funding of the research. The views expressed herein are those of the author and do not necessarily reflect those of the OECD or its Member countries.

Contact information: Fellow of the Canadian Institute of Actuaries (FCIA) and Fellow of the Society of Actuaries (FSA), USA. Chemin de Peire Luche 06330, Roquefort-les-Pins, France. Email: colin.pugh@ wanadoo.fr
} 
longevity. The challenges to the regulatory authorities thus continue. There are no easy solutions. There is still no clear best practice that (i) reassures the pension plan beneficiaries and conservative regulatory authorities in sustained periods of severe economic downturn, but (ii) does not aggravate the country's wider economic problems and (iii) still encourages the sustainable development of occupational pension plans in the years ahead. It will be counter-productive to become excessively distracted by the current economic issues, so each issues addressed in this report first will be analyzed in the environment of more normal times. The effectiveness of each conclusion in a sustained economic downturn then will be tested, but without the automatic expectation that it will always satisfy the concerns of all stakeholders.

\section{Pension plans that are the focus of this report.}

3. Although various aspects of this paper have wider application, the focus is on occupational defined benefit pension plans financed through autonomous pension funds. Clarification of these terms will be provided throughout this report, and reference also should be made to the OECD's "Taxonomy for pension plans, pension funds and pension entities".

\section{Lump sum pension benefits.}

4. For the purposes of this paper, it does not matter whether the retirement benefit is paid in periodic instalments (generally for the lifetime of the retired employee and spouse) or whether it is paid in a single lump sum at retirement. The advance funding considerations are virtually identical.

\section{Long service or termination indemnities.}

5. Long service indemnities or termination indemnities of the defined benefit type also would fall within the scope of this paper - if they are paid automatically on retirement to anyone fulfilling the eligibility requirements, and if such obligations are or were to be externally funded. 


\section{SECTION 2: HISTORICAL DEVELOPMENT OF FUNDING REGULATIONS}

6. This report will focus almost exclusively on the roles of the regulatory authorities as they relate to the external funding of DB pension plans. Pension plan regulators clearly have broader responsibilities, but the OECD is addressing these issues in other research papers and other conference sessions. "Funding" is already a large subject, and a very topical subject, so it will be productive to focus the mind on this single issue.

\section{Development of Regulatory Environment.}

7. There are primarily two governmental bodies concerned with the regulation of occupational pension plans and pension funds - the labour, social affairs and social security ministries on the one hand and the economic and financial authorities on the other. Among the latter, the tax authorities have played historically the more dominant role. They set the conditions under which employees and employers could make contributions - often tax deductible contributions - to a plan, and they still control this aspect. Their regulations affect both plan design and plan funding. The tax authorities were, and still are, concerned about (a) the payment of excessive benefits to some or all plan members and (b) the deposit of unnecessarily high, tax favoured contributions into the pension fund. These are, of course, legitimate concerns. In the 1990s, they perceived their greater challenge to be the accumulation of large funding excesses (surpluses) within pension funds - not because of deliberately excessive employer contributions, but simply because investment performance far outstripped the actuary's expectations for a sustained period of time. The knee jerk reaction was additional, and often very counterproductive legislation, although it is unfair to place all the blame on the tax authorities. This point will be covered in more detail in other sections of this report.

8. It was only later (the mid-1960s in Canada, 1974 in USA, etc...) that the labour and other ministries became more actively involved in pension plans, and their focus was substantially different. The thrust of legislation from this quarter is the establishment and protection of plan members' rights. This involves many aspects of plan design, as well as prudent investment of fund assets and sound funding of the pension plan obligations. The last item is of direct relevance to this report. Minimum funding standards were an integral part of the original legislation, but (in retrospect) the initial requirements were not particularly onerous. In simple terms, the general requirements were for payment of:

- the current year's normal costs (as defined by the actuarial funding method);

- a slow amortization of any initial unfunded liability existing at the time the legislation was introduced or a new pension plan was established;

- slow amortizations of subsequent increases in past service liabilities resulting from retroactive plan improvements;

- sensible amortizations of “experience deficiencies", i.e. unfavourable deviations from the actuary's forecasts (high salary increases, low investment returns, etc...).

9. The legislation in some countries did not break down the payments in this manner, but the overall intent was similar. Later, for a variety of both positive and misguided reasons, the legislation in many countries became far stricter. There was, and continues to be, considerable emphasis on "minimum funding standards", but the rules of the game have changed. These requirements will be discussed in Section 4 of this report and analyzed in detail in the country appendices. 


\section{SECTION 3 : GENERAL ACTUARIAL CONSIDERATIONS}

10. This section will address actuarial funding methods and actuarial assumptions from the perspective of the regulator. The fundamental question is the extent to which pension law or the pension regulator should mandate the use of a single actuarial funding method or prescribe the actuarial assumptions? These and other questions will be addressed in general terms in this section and then analyzed in more specific detail in the subsequent sections on minimum funding requirements (Section 4) and maximum funding constraints (Section 5). Appendix "A" summarizes the most important actuarial funding methods and identifies their key characteristics and objectives. Anyone unfamiliar with actuarial methodology should first read the appendix and then return to this section. Country-specific legislation on actuarial methods and assumptions is provided in Appendix " $\mathrm{B}$ ".

\section{Should regulators mandate a single actuarial funding method?}

11. It is difficult to justify mandating a single actuarial funding method. Employers in different industries or at different stages of their development (from start-up to mature) will have correspondingly different funding objectives. All the actuarial funding methods described in Appendix A are sound and systematic, and the use of any of these methods should not cause concern to a regulator.

\section{Is "Projected Unit Credit" becoming the norm?}

12. In the absence of any particular legislative constraints or other outside influences, there has been a trend in many countries towards Projected Unit Credit. An easy example is the UK, where the Aggregate method was dominant for a very long time and Projected Unit Credit (PUC) was hardly to be seen. However, long before UK accounting standards pushed PUC for pension expensing purposes, the method took hold. In Canada, PUC has been dominant for decades, again before outside influences. One must then ask whether the popularity of PUC is justified, and the answer is almost certainly "yes". It is more transparent than most other methods, and it produces a form of balance sheet that most people can understand. Its definition of accrued liabilities is clear and readily comparable with the accumulating fund assets. Favourable and unfavourable experience is easy to identify and understand. Finally, and more recently, there is one major defensive reason for using PUC. It is the method selected by the major accounting bodies for the pension expensing requirements that are being imposed on plan sponsors. Perhaps, accountants were also convinced of the transparency and other advantages just described. There is certainly no necessity to use the same actuarial method for funding and expensing, but there are obvious advantages.

\section{Should regulators prescribe the actuarial assumptions?}

13. In answering this question, there are a number of separate issues to be addressed. If we start by focusing on the regular funding of the plan, and we temporarily set aside any concerns of minimum funding standards and maximum funding constraints, then the regulators should mandate nothing more than the use of reasonable and appropriate assumptions. In this context, the major assumptions should be independently realistic, with perhaps a margin of conservatism (prudent assumptions). The reasonableness of the minor assumptions can be evaluated in aggregate. This is already the legislative environment in many countries, although a combination of cultural, psychological and legislative factors restricted the use of this approach in the Netherlands and Switzerland until quite recently (see appendices). As regards minimum and maximum funding constraints, the question is more difficult to answer, simply because assumptions can be used to manipulate the results. For example, a high discount rate and a weak mortality table can make a plan appear to be better funded than is really the case ... and vice versa. 


\section{Should regulators prescribe the valuation of assets?}

14. This question should not be answered in isolation. Assuming a realistic and somewhat marketrelated valuation of the liabilities, most players now agree that fund assets should be brought into the equation on the basis of either their straight market value or some smoothed market value. The disagreement is over the validity of smoothed values. The accounting profession clearly does not like them, and others claim that smoothed values are a distortion of reality and tend to shield the plan sponsor from facing up to such realities. However, the objective of a pension fund is to accumulate assets on a sound and systematic basis. From a long-term funding perspective, is a market valuation on a single date (that is already some months in the past) really so important?

15. Forcing or encouraging plan sponsors to take dramatic corrective actions based on this single market value can be very counterproductive, and it is an issue that is developed in greater detail in Sections 4 and 5. Numerous proposals are provided in these sections, so only one additional point will be made at this time. Even if smoothed market values are rejected, and fair market values must be used at all times, large and unnecessarily volatile swings in contribution rates can still be avoided. This is where the question of asset values cannot be answered in isolation. If the effects of experience gains and deficiencies revealed in an actuarial valuation are allowed to be spread over a reasonable period of time (e.g. at least five years), then there is still implicit smoothing. If the market value of the assets was only a temporary aberration, the amortization can be stopped before it aggravates the real funded position of the plan. Some smoothing is highly desirable - in one form or another - but which form?

\section{Correction of overfunding and underfunding.}

16. With the sole exception of the Aggregate method, the actuarial funding methods described in Appendix A do not prescribe the amortization of any experience gains or deficiencies. [At this point, we are concerned with the overall effect of positive and negative deviations from the actuarial assumptions, not just the investment gains and losses.] These actuarial methods, including the Projected Unit Credit, simply indicate that the plan is overfunded or underfunded. There are then subjective decisions to be made regarding whether to ignore the excess or the shortfall or, alternatively, how to correct it. Unless the funded status of the plan is close to the minimum funding requirement or the maximum funding constraint, the plan sponsor should be allowed a fair degree of flexibility.

\section{Frequency of Mandated Valuations?}

17. The choice is usually between one and three years. It is rather strange that nobody has thought of two years, although it is clear that one year is too short in most circumstances and three years is too long. The accountant's pension expensing standards may push plans towards annual valuations. Furthermore, annual valuations make sense when the plan is seriously underfunded or the experience is volatile. From a regulatory standpoint, a maximum interval of three years is probably still appropriate, with more frequent valuations of poorly funded plans.

\section{Pension expensing considerations.}

18. Many of the accounting-related issues and influences on funding have already been addressed. One remaining question is then whether a plan sponsor should try to match the pension plan funding with the pension expense, primarily in order to eliminate any pension asset or liability on the company's balance sheet. The answer to this question is "no". Some American employers attempted this in the late-1980s. In practice, it does not work. Now, given the proposed changes in accounting standards, it would generate highly volatile and thus highly undesirable funding requirements. 


\section{SECTION 4: MINIMUM FUNDING STANDARDS}

\section{Background.}

19. Minimum funding requirements usually are to be found in legislation focused on protecting the plan members' benefits and, in particular, on ensuring the security of the payment of such benefits. The source is normally labour and social affairs legislation, but financial and tax authorities also regulate funding requirements. As already indicated in Section 2, traditional minimum funding requirements focused on payment by the plan sponsor of the normal or current service cost plus maximum amortization periods for various categories of unfunded liabilities and experience deficiencies. These requirements still exist in many jurisdictions, but they have been overtaken in importance by straight asset/liability measures.

\section{Asset/liability measures.}

20. In many countries, the minimum funding standards focus on the pension fund assets exceeding the pension plan's accrued liabilities on every measurement date. Almost every country with such a standard has its own way of defining "accrued liabilities", and often there are various requirements for valuing the fund assets (see below). However, the basic philosophy is the same. The authorities are focused on "benefit security" (a laudable objective), and the standards equate such benefit security with the crude size of the pension fund assets. In truth, benefit security depends on many other factors, such as the financial strength of the sponsoring employer, its future intentions regarding the pension plan and the funding thereof, the quality of the fund assets relative to the liabilities, verifying whether the assumed rate of return is reasonable, etc... It is easy to accept the weaknesses of the simple asset/liability solvency measures. It is far more difficult to develop a viable and effective alternative.

\section{Calculation of Accrued Liabilities.}

21. For the purposes of minimum funding standards, most regulatory authorities define the "accrued benefits" and then specify the discount rate to be used for the calculating the present value of such accrued benefits (i.e. the accrued liabilities). For these purposes, common definitions of accrued benefits include vested benefits payable on termination of employment and benefits payable to the members in the event the plan were immediately terminated. The prescribed discount rate usually takes the form of (i) a specific rate, (ii) the current market yield on an identifiable group of securities or (iii) the rates implicit in the purchase from insurance companies of immediate and deferred annuities. In some countries, it is simply a maximum rate (e.g. $6 \%$ pa in Belgium).

\section{Basic criticism of annuity purchase assumption.}

22. As already indicated, many solvency tests implicitly or explicitly assume (i) immediate termination of the pension plan, followed by (ii) immediate liquidation of the fund assets and (iii) immediate purchase of insured annuities. If a pension plan cannot successfully discharge all three of these assumed steps, it is deemed to have serious funding problems that requires drastic actions. However, in all except the rarest circumstances, none of these assumptions is logical. Even if the plan were terminated, the solvency test makes an unwarranted assumption as to the future strategy of the pension entity administering the plan. An immediate sale of all assets and transfer of the proceeds to an insurance company is most unlikely, especially for a large fund or if market conditions are unfavourable. These concerns become even more worrying if the solvency test explicitly assumes annuity purchases, and the current annuity market is (for one reason or another) simply uncompetitive. Ireland is one country where this issue is already being discussed. 


\section{Over-regulation.}

23. Over-regulation of DB pension plans is an unfortunate and growing phenomenon; see Section 5. The Myners' report in the UK, when reviewing the UK's minimum funding requirement and other UK regulations, argued that increased protection under DB plans will deprive employees of having any DB plan at all. Instead, such plans will be replaced by DC plans, and all the risks will then be thrown at the employees. In the area of minimum funding, as with other areas of legislation, there is a fine line between (over)protecting the interests of DB plan members and destroying the incentives for employers to sponsor such plans.

\section{Minimum funding $v$. fraud.}

24. The UK's minimum funding standard (the MFR) was a reaction to the Maxwell scandal, where pension fund assets were fraudulently removed from the Mirror Group pension fund. Minimum funding standards of the asset/liability type described above do not prevent fraud. Indeed, most pension legislation cannot stop a determined criminal. However, minimum standards that pay more attention to the quality of the fund assets and the good intentions of the employer can be an important step in the right direction.

\section{Conclusions.}

- The assumptions used for calculating and comparing assets and liabilities should not necessarily be the same for all pension funds. A single set of assumptions fails to recognize fund-specific factors such as the maturity of the fund, the strength and future intentions of the plan sponsor, and the investment strategy of the pension entity.

- The whole situation becomes even further detached from reality under the plan discontinuance and annuity purchase type of solvency test.

- Solvency tests should not protect against all possible economic scenarios (such as the fourth or fifth consecutive year of an economic downturn). The costs would be too high. Pension funding should not take priority over the very survival of the plan sponsor, and the wider economic impacts could be disastrous. See "Netherlands" in Appendix B.

- Solvency tests would be better focused if they encouraged optimal investment of the fund assets and protected plan members against inappropriate investment strategies. Such assessments should be fund-specific. Asset liability modelling (ALM) studies can play an important role in this regard.

25. Of course, the final question is whether minimum funding tests serve any useful purpose. If not, they should be abandoned in favour of other requirements on the sound management of the plan and fund (governance and other issues). If they are still deemed to be necessary, they should be more plan-specific and they should avoid the imposition of volatile funding or other detriments to the smooth functioning of the plan. In moving away from the MFR, the UK authorities are indeed trying to move towards a more plan-specific approach.

\section{Recommendations.}

- Monitor the discussions taking place among regulators and within the actuarial profession in both Canada and the USA, and in the UK and elsewhere in Europe. Many experts are searching for better alternatives to today's crude asset/liability measures for measuring funding adequacy and protecting the members' security. Their efforts should be encouraged. 
- If an asset/liability type of minimum funding measure is to be introduced or retained, then legislation should not require the immediate and complete correction of any underfunding that the test purports to reveal. Actuarial calculations are an inexact science. Asset values fluctuate, and funding shortfalls may disappear as quickly as they had appeared. It is counterproductive for a plan sponsor to make high additional contributions and then find, one or two years later, that the markets have recovered and the plan now has an embarrassing funding excess (see next section).

- Continue to refine approaches that avoid excessive knee jerk reactions to underfunding, include ignoring small funding shortfalls (say, 10\% of liabilities), smoothing asset values and amortizing shortfalls over five years. Whilst acknowledging the inherent weaknesses of any asset/liability solvency measures, and recognizing the slight differences between the various supervisory authorities in Canada, there is much to recommend the general Canadian approach to minimum funding. The objective is clear and logical. The five-year period for corrective action avoids dramatic knee jerk reactions to deficits in times of temporarily distorted market conditions. The combined smoothing of asset values and discount rates, as allowed by some of the Canadian regulators, also can work well.

- The regulator should allow additional flexibility in a sustained economic downturn. 


\section{SECTION 5 : MAXIMUM FUNDING CONSTRAINTS}

\section{Background.}

26. Maximum funding constraints are imposed by tax authorities to prevent either the deliberate or accidental build-up of excessive assets within the pension fund. Deliberate build-ups were the result of a plan sponsor consciously contributing far more to the pension fund than was needed to finance the promised benefits. Only pension people with long memories can remember those days! Accidental buildups of excess funds result primarily from favourable experience under the plan. With the benefit of hindsight, the actuary's assumptions were too conservative. High investment returns or other favourable plan experience caused the assets to grow at a faster pace than the accruing liabilities. This was the focus of attention of the tax authorities during the late-1980s and the 1990s.

\section{Sanctions and Corrective Actions.}

27. In most countries, tax legislation does not impose direct sanctions on plan sponsors or pension funds in the event of overfunding. There are examples of special excise taxes (USA) or additional taxes on withdrawals of excess assets (UK), but most jurisdictions focus on requiring the plan sponsor to take corrective actions. The most common, and most obvious, corrective action is the reduction of future contributions. Even in the absence of government legislation, these downward corrections of contribution rates are an automatic part of ongoing discussions between the actuary and the plan sponsor. Then, in the 1990s, plan sponsors were happy to go even further than the actuary would normally recommend. They happily agreed to complete contribution holidays, and they explained their actions as being a consequence of government legislation.

28. Another important approach to reducing overfunding is for the plan sponsor voluntarily to spend the money, through improvements in the accrued benefits of non-retired members, increases to pensionsin-payment and guarantees of future pension indexing. This approach only becomes contentious when the regulator mandates such actions. The third main approach to reducing overfunding is the refund of excess assets to the plan sponsor. Such withdrawals are explicitly forbidden in some countries, e.g. Belgium and Switzerland. For all practical purposes, Canada can also be categorized as a country where withdrawals of excess assets have become impractical.

29. Of course, one has to ask whether any of these corrective actions were really necessary or desirable. We are now facing a pensions funding dilemma, for which blame can be widely apportioned. Without excusing plan sponsors and their advisors, it is clear that government legislation is counterproductive when it encourages or requires rapid and vigorous corrections of either the perceived overfunding of the 1990s or the subsequent (and somewhat consequential) underfunding of the early 2000s.

\section{Ownership of Funding Excesses.}

30. In the very large majority of countries and situations, it is the plan sponsor (the employer) that is fully responsible for correcting any underfunding situations. It should therefore not be a great leap of faith to conclude that the employer should be the beneficiary of any temporary overfunding. Indeed, some of the actuarial costing methods involve the conscious creation of such advance funding, to underpin the basic objective of a smooth employer contribution rate. However, overfunding or advance funding is frequently re-categorized into the far more emotive word "surplus". Anyone familiar with the pension environment during the 1990s will remember the highly emotional, and even confrontational, discussions on the ownership and application of such surpluses. The equation has become unbalanced in several countries 
where, in practical terms, funding shortfalls are the employer's problem and funding excesses belong to the members. In such an environment, no employer is going to move beyond minimum funding. This is very unfortunate. Unless plan sponsors can be convinced of their right to the upside gains as part of their responsibility to accept the downside risks, solid funding of pension obligations will become history. Future generations of plan members and plan sponsors will curse our short-sightedness. It should be noted that there are some countries where the responsibility for covering any funding deficiency is shared, or can be shared, partly with the plan members; in these circumstances, the treatment of any funding excess would need to follow a consistent approach.

\section{Accelerated funding under some actuarial funding methods.}

31. As discussed in Section 3 and Appendix A, some actuarial funding methods require heavier contributions in the early years in order to stabilize future contribution rates. A practical side effect of these accelerated contributions is an additional hedge against unanticipated and unfavourable future experience. If government legislation then requires the funded position of all pension plans to be assessed on an accrued benefit basis, these particular plans will appear to be overfunded even when plan experience has conformed largely to actuarial expectations. If this factor is not taken into account in any governing legislation, then the practical effect is to restrict the choice of actuarial funding methods and reduce funding levels.

\section{Investment reserves and smoothing techniques.}

32. Notwithstanding some of the above concerns, the tax authorities still have a right to be concerned about any plan sponsor that attempts to abuse the generally tax-favoured status of occupational pension plans. However, their concerns should not be aimed at penalizing prudent plan sponsors that simply want to fund their pension obligations on a sound and conservative basis. The other main challenge for the regulator is to avoid demanding drastic corrective actions when overfunding is simply the result of recent, and perhaps temporary, market conditions. As events have shown, overfunding can disappear as quickly in the years immediately following an actuarial valuation as it had been generated in the years immediately preceding such a valuation. From a regulator's standpoint, there are three solutions to these challenges that parallel a sensible treatment of underfunding, namely:

- Smoothed asset values. For the purposes of determining whether a plan is genuinely overfunded, and the extent to which it is overfunded, the plan sponsor should be allowed to use a smoothed market value for the assets. Alternatively, fair market values can be specified, but a pension fund would be allowed to maintain an additional investment reserve when asset values are high. The end result is the same, but there are important differences in the presentation.

- Margins. In the same manner as most authorities do not require any action to be taken for underfunding of less than $10 \%$, a similar (but preferably higher) margin could be allowed for overfunding.

- Amortizations. Any "correction" of overfunding should be allowed to take place over a sensible period of time.

33. However, there is one additional consideration that differentiates overfunding from underfunding. While it is clearly undesirable to continuously ignore a funding shortfall, is there any reason to prevent a pension fund continuing to retain a modest funding excess? If pension funds had been allowed to retain contingency reserves, and if the "ownership" issues surrounding such reserves could be more favourable to the plan sponsor, pension funds would have been in a better position to weather the current underfunding problems. 


\section{Conclusions and solutions.}

34. Using the term "pension plan regulator" in the narrower sense, namely the administrators of legislation protecting members' rights, these regulators would have no problems in allowing or even encouraging overfunding. The legislation surrounding the ownership of excess funds is usually found elsewhere, and often in the Courts. The legislation establishing maximum funding constraints usually emanates from the tax authorities. This is a classic example of the need for effective cooperation between the somewhat competing priorities of various parts of government. Desirable solutions include:

- Resolution of the current no-win situation for plan sponsors in many countries regarding the correction of experience shortfalls (deficits) and the utilization of funding excesses (surpluses);

- Tolerance of a reasonably large amount of overfunding by the tax authorities. There should continue to be measures to prevent abuse, which is normally confined to small plans. Ireland is one country where the focus of the regulators is the correction of genuine abuse without the penalization of plan sponsors seeking conservative funding.

- To the extent overfunding is so high as to demand corrective actions, the plan sponsor should be permitted to amortize the corrective actions over a reasonable period of time. In Canada, for example, there are no requirements for dramatic action even when the surplus exceeds the established threshold. The plan sponsor can simply take a contribution holiday until the excess funding is used up. If the funding excess was just the result of temporarily distorted market conditions, then the contribution holiday will be short and regular funding can resume.

35. It will not be easy to persuade some legislators to make these changes. However, there will never be a better time than now. People are coming to understand that aggressive and counter-productive treatment of overfunding in the 1990s is one of the primary reasons for the current underfunding. 


\section{SECTION 6 : CHALLENGES FACING REGULATORY AUTHORITIES}

\section{Introduction.}

36. The challenges identified in this section are particularly relevant to the regulation of pension plan funding, although some are equally applicable to plan design or the investment of fund assets. There can also be complicated areas of overlap, for example when an apparently sound funding regulation has the potential to create adverse consequences on plan design or the investment of fund assets.

37. The primary objective of this section is to set out the difficulties facing any legislator and to learn from the positive and negative experiences in other countries. The challenge for the government and the regulator is to move towards pension funding regulation that:

- has clear and agreed objectives;

- is transparent, avoiding convoluted methodology or artificial assumptions;

- is capable of being understood by non-experts;

- is effective in practice, avoiding unnecessary cost burdens such as administrative overload or inefficient investment practices; and most importantly

- encourages the establishment and continued maintenance of occupational pension plans.

38. In most of those countries with a long history of pension plans, there is a widespread fear in the business community that pension plan and pension fund laws and regulations can become excessive and even counterproductive. Regulators have a very important role to fulfil. It is a great challenge for them to satisfy the legitimate concerns of all stakeholders (pension plan sponsors, their shareholders, pension plan members and other beneficiaries, etc...) whilst avoiding unforeseen or undesirable consequences for the plan sponsor or the general economy. From the perspectives of both the regulator and the regulated, some of these challenges now will be identified. For those countries in the development stage of pension plan regulation, there are many useful lessons to be learned.

\section{Challenges.}

39. A stable legislative environment. An environment of constantly changing legislation and regulations is not conducive to the smooth and efficient operation of pension plans and funds. Countries such as the United Kingdom might be a consultant's dream, but they can be an employer's nightmare. The competing effects of the UK's minimum funding requirement (MFR) and maximum funding constraints caused considerable confusion. More recently, the frequent changes to Dutch funding legislation have become a cause for concern. The Dutch regulator prides itself on "continuously updating it supervisory regime", but this can be a two-edged sword. It was not so long ago that Dutch past service liabilities could be book reserved on a tax effective basis and other unfunded liabilities and experience shortfalls could be amortized through to retirement (the so-called 65-x method). In 2000, the 65-x method was abandoned in favour of full and immediate funding; a 10-year transition was allowed. In 2003, additional reserves were then required in connection with equity investments and for the unamortized portion of the 10-year transition. Although some of the early changes had little practical effect at the time, because of inflated asset values, an environment of constantly shifting sands was discouraging. Further, very significant changes in funding regulations were then promised for 2006 (since deferred until 2007); see Appendix. 
40. Although plan sponsors may not like some parts of any country's pension legislation, they eventually learn to adapt and comply. Obviously, this is easier when the legislation is not undergoing constant change and where there is a consistency of approach. Switzerland provides a good example of a more stable environment. Swiss pension legislation is scheduled for a thorough review only every ten years, and there is comprehensive input from all quarters. There is only fine-tuning of the legislation in the intervening years, and usually as a consequence of well-reasoned requests from plan sponsors and others. One example has been the acceptance of asset liability modelling studies to support efficient pension fund investment strategies that otherwise contravened the quantitative investment restrictions.

41. A stable funding environment. Plan sponsors should be allowed to fund their pension obligations in a controlled manner, without the knee-jerk volatility imposed by funding legislation in some countries and without the pressures imposed by other outside influences. Plan sponsors are very concerned about the extreme volatility of pension expense that can be imposed by evolving accounting requirements. Translating that level of volatility into pension funding could be catastrophic. The next two points expand on this issue.

42. Smooth correction of underfunding. This issue has already been developed in detail in Section 4. Even if smoothing is allowed in the calculation of accrued liabilities or the valuation of assets, actuarial calculations are an inexact science and asset values are volatile. Amortization of any funding shortfall should be allowed over a reasonable period of time. If no smoothing is allowed in the underlying calculations, then such amortizations (and the use of "corridors") become even more important. The minimum funding approach developed by the Canadian Institute of Actuaries achieves a fine balance in this regard (the problems in Canada lie elsewhere, in that customary funding could default to this minimum funding standard). The challenge for the regulator is to allow some smoothing, either in the calculations or through amortizations, without completely destroying the credibility or transparency of the results.

43. Constructive approach to overfunding. Some of the same considerations apply to overfunding. However, there is an important fundamental difference. Underfunding is a problem, whereas overfunding is an opportunity - an opportunity to set aside reserves to protect against future adverse experience and to introduce further stability into the funding of the plan's obligations. In many countries, the various arms of government need to work in a more coordinated manner to ensure a constructive approach to overfunding.

44. Additional flexibility in difficult times. More than 70 years have passed without a sustained economic downturn of the type recently experienced. As a result, many governments and regulators explicitly relaxed their funding requirements on a temporary basis (e.g. Ireland, UK and USA). In a number of other countries, the regulators have taken a more flexible attitude to short term funding (e.g. Portugal). The Netherlands, which introduced much more stringent funding requirements during the depths of an economic downturn, also found it necessary to counterbalance this effect with additional dialogue and flexibility.

45. A Pension Fund is not an Insurance Company. A pension fund of the closed type, which is the primary focus of this report, does not sell products. Indeed, it is the opposite, as it is a buyer of services and products. It does not deal with the general public. Only in rare circumstances does a pension fund make guarantees. It is the plan, and thus the plan sponsor, that normally makes promises (or even guarantees) to the plan members; it is not the fund. Yet, many countries persist in regulating pension funds as if they were insurance companies or insurance products. Funding standards, and especially minimum funding standards are erroneously geared to insurance company products, guarantees, reserving and overall philosophy. Pension fund legislation that talks about "premiums" rather than contributions, and "mathematical reserves" rather than accrued liabilities, often reflects this approach. The debate about the requirements for a "level playing field" between pension funds and insurance companies may have complicated these issues. 
46. The insurance supervisory authority is, in several countries, responsible also for pension fund supervision - this is not always a problem, and it is sometimes necessary in smaller pension markets with limited actuarial expertise, but the regulator (and the legislation itself) must recognize the unique characteristics of pension funds. Portugal is a good example of an insurance supervisory authority that has been charged with pension fund supervision and is able to make the clear distinction. In contrast, the Netherlands published a so-called White Paper on the Solvency Test, "by means of which the capital adequacy of a pension fund or an insurer is assessed" - and which appears to assume that a pension fund and an insurance company are identical twins and should be regulated as such.

\section{Problems (real and perceived).}

47. Unrealistic expectations. Some plan members, their representatives and other parties have developed unrealistic expectations about the roles of regulators in curing all the world's pension problems. One obvious example was the UK's minimum funding standard (MFR). It was not only supposed to prevent fraud of the Maxwell type, but it gave most people the impression of providing iron-clad guarantees of the funding of their accrued benefits. Iron-clad guarantees are too expensive, and fundamentally inefficient, but that is a separate and even more complex issue. The MFR was nothing more than its name indicates - a minimum funding requirement. However, it created unrealistic expectations, and regulators need to be aware of this type of potential problem.

48. Over-regulation. There is strong evidence that this is the second most important reason for employers switching from defined benefit (DB) pension plans to defined contribution (DC) pension plans, with the first reason being the potentially volatile costs of DB plans. Over-regulation is indeed a serious problem, and it should not be underestimated by government authorities in developing pension plan markets. DB pension plans are inherently superior to DC plans in a number of important areas, but they are being legislated to death in some countries. This point is covered below in more detail.

49. Counter-productive legislation. There is a lot of discussion on this point at the present time. In the same way as a doctor treats a sick patient, the regulator must be careful to cure a problem without creating numerous and more serious side-effects elsewhere. One example will serve to illustrate the point (see next paragraph).

50. Distortion of investment decisions. Much very valuable work has been done in recent years to improve the effectiveness of pension fund investments. Asset liability modelling (ALM) studies have played a major role in this regard. For various degrees of risk tolerance and with the specific demographic and other characteristics of an individual plan, it is now relatively simple to develop a range of efficient portfolios for the fund. The results have been revealing, sometimes surprising and always useful. As already indicated, Switzerland has agreed to relax its complicated asset mix restrictions, if it can be shown that they are "inefficient" for a particular fund. The EU pension fund directive almost completely abandons quantitative investment restrictions, in exchange for a prudent person rule and the encouragement to use ALM. However, the progress achieved through the front door is in danger of being lost through the back door. For example, minimum funding standards in many countries are designed around insurance company annuity rates or current market yields on long-term bonds. In order to avoid problems, especially in jurisdictions that require immediate correction of the (perceived) underfunding, a plan sponsor is tempted to over-invest in such long-term bonds. Some legislation on the indexation of pension benefits can have the same effect. Although outside the realm of the pension regulator, proposed amendments to international, UK and perhaps US pension expensing standards may again push plan sponsors away from equities and into more bonds. However, pension plans in the long term, especially those providing benefits based on final-average salaries, need substantial investments in equities. Otherwise, the investments may be inefficient, and the cost of the pension plan to the plan sponsor will therefore increase. 


\section{Undesirable Consequences.}

51. A funding strategy based on avoidance of overfunding. This issue has already been mentioned, but it bears repeating. Unless issues surrounding ownership and control of funding excesses can be resolved, plan sponsors will simply aim for minimum funding, perhaps with the smallest of contingency margins. This type of approach is in nobody's long term interests. The negative impacts were painfully illustrated during the recent economic downturn.

52. Increases in costs. One point is the direct administrative and consulting costs incurred in complying with a growing body of pension legislation. Plan sponsors repeatedly complain about these costs, especially in regard to defined benefit plans. Filling out government forms, and hiring advisors to provide numerous certifications, is a reality of life - an easy source of frustration, but a necessary part of doing business. As regards pension plans, the real concerns are elsewhere. As already described, the most serious indirect cost impacts stem from the legislative requirement or encouragement to invest the fund assets in an inefficient manner. There are other examples.

53. Switching to DC plans for the wrong reasons. For a while, many employers believed they were switching from defined benefit to defined contribution plans because they thought it was a good idea for everyone concerned. However, DC plans are not inherently superior. They are different, and they have many weaknesses that are only starting to be understood by the majority of the population. Employers now readily acknowledge that the switch to DC was really because of their concerns about the uncertainty and potential volatility of DB plan costs. Their concerns are only partly justified, because a well-designed DB plan that is funded in a systematic manner can be quite stable. Much of the fuel for their concerns was supplied by legislation that removed the basic flexibility to fund "in a systematic manner", and probably also by accounting standards.

54. Abandoning pension plans altogether. This is simply an extreme extension of the concerns expressed in the previous paragraph.

\section{In Summary.}

55. In an era of reducing (first pillar) social security benefits, there must be proactive encouragement to employers to establish and maintain occupational pension programs. Tax legislation can provide important incentives. In a minority of countries (e.g. Ireland), the pension regulator also is charged with encouraging the growth of occupational pension plans. In all countries, pension regulators have the challenge of discharging their supervisory responsibilities without discouraging the continuation of the very plans they are attempting to protect. Not an easy task. 


\section{SECTION 7: RECENT TRENDS AND DEVELOPMENTS}

56. As already indicated, the first version of this report was written in 2003. Much has happened on the regulatory front during the intervening period. Indeed, several jurisdictions have started directly to address many of the concerns identified in this report. This Section 7 will highlight and comment on several of these changes. Technical descriptions are to be found in the updated individual country profiles in Appendix B.

57. Plan-specific funding requirements. As part of its Pensions Act 2004, the UK is moving towards plan-specific funding requirements. These will replace the misunderstood and much maligned Minimum Funding Requirement (MFR). Each occupational pension plan now is required to adopt a Statutory Funding Objective. The actuarial costing method is not prescribed, although it must be one of the family of accrued benefit costing methods. Similarly, the economic and demographic assumptions and the discount rate for calculating the liabilities are not prescribed, but they must be prudent. In preparing a recovery plan to address any funding shortfall, the trustees (in consultation with the plan sponsor) must take into account the asset and liability structure of the plan, its risk profile, its liquidity requirements and the age profile of the members. It is anticipated that amortization periods will be relatively short, although this will require some level of consultation and even negotiation between the trustees and the plan sponsor.

58. Relaxation of minimum funding requirements. Several jurisdictions have relaxed their minimum funding requirements, most specifically in the area of longer amortization periods for addressing funding shortfalls. Some of these concessions are announced as being temporary, and conditions often are attached. Bill 102 in the Province of Quebec, proposals under discussion in other Canadian jurisdictions, Ireland and Switzerland all provide examples of these changes.

59. Tightening of minimum funding requirements. The Netherlands dramatically reinforced its minimum funding requirements in 2002-2003. These requirements will be replaced in 2007 by a new standard called the Financial Assessment Framework (FTK). Depending on the circumstances, the FTK could represent either a relaxation or a further tightening of the current funding requirements, but definitely a tightening of the pre-2003 requirements. One way or another, the current and future Dutch regulations would be classified as conservative in relation to almost all other jurisdictions.

60. Letters of Credit. There are several variations of this theme. A typical example would be the plan sponsor purchasing a letter of credit from a bank, as part of the plan sponsor's general credit facility. The letter of credit could, for example, cover the pension plan's solvency deficit or the foregone solvency amortization payments. The letter of credit would be held by the trustee of the plan and fund, and it would be called upon in the event the plan sponsor defaults. The letter of credit would be counted as a plan asset, but normally only for minimum solvency valuation purposes. This concept has been introduced in Quebec Bill 102, and it is being widely discussed in other North American jurisdictions.

61. No benefit improvements by severely underfunded plans. Relaxed funding requirements in some jurisdictions have been accompanied by tighter constraints on making plan improvements. The basic thrust is to avoid further aggravation of the funded position of an already seriously underfunded plan. For example, Quebec Bill 102 forbids all plan improvements unless any resultant increase in accrued liabilities is fully and immediately funded. The new pension funding reform in the USA would, with few exceptions, forbid plan improvements being made by severely underfunded plans. Indeed, if the funding ratio falls below $60 \%$, future regular benefit accruals also would be in jeopardy. 
62. More constructive approaches to overfunding. Many jurisdictions are becoming increasingly cognizant of the problem, but no simple and effective solutions have yet been found. Indeed, it is the tax authorities and the courts that are the sources of many of these unfortunate constraints on conservative funding, so the pension legislator often is unable unilaterally to address the issues. Some progress has been made in regard to relaxing the tax regulations on maximum funding, e.g. in the USA, where current pension reform envisages a return to the higher limits of prior years. The tight UK $105 \%$ maximum funding limit also is being changed. From the perspective of both jurisprudence and pension law, the 2005 Canadian federal government consultation paper on funding reform requests input on "whether there are any disincentives or obstacles preventing plan sponsors from adequately funding their plans and building up a funding cushion". The document acknowledges that: "Many plan sponsors and experts have argued that there may be an apparent asymmetry in surplus ownership under (government regulations). They argue that (government regulations) have the effect of requiring plan sponsors to share any surplus while remaining fully responsible for pension plan deficits." The problems have already been discussed in Section 5 of this report. They are important, and solutions need urgently to be found. Otherwise, plan sponsors will just aim for minimum funding at all times, and this is in nobody's best interests. This is not to pretend that the solutions are easy. Some countries do not even see it as a problem; they legislate that funding excesses belong entirely to the plan members ... in full, and under all circumstances. For most plan sponsors operating in these countries, conservative funding and overfunding are unsound philosophies.

63. DC funds retaining the annuity and Hybrid Plans. A hybrid plan is generically defined as a pension plan that shows features of both defined benefit and defined contribution plans, and there have been at least four main developments in this area. First, cash balance and other hybrid pension plans have simply become more widespread. Second, there are a growing number of plans that seem to be defined contribution, but that include a minimum guaranteed rate of return. The cause either may be government legislation (e.g. Belgium and Germany), plan sponsor choice or collective bargaining. These plans are, in effect, "better of" plans, where the plan member receives the higher of a pure DC accumulation and a defined benefit. Third, there are defined contribution plans in some countries (e.g. Brazil) where the pension fund converts the retiring employee's DC accumulation into an annuity and retains the annuity obligation in the fund - rather than purchasing an annuity from an insurance company. The fourth development is an inevitable consequence of the first three; governments and accountants, actuaries and other specialists acknowledge that all of these types of arrangements need to be treated as defined benefit plans for the purposes of expensing and actuarial funding. In particular, governments and pension regulators now are explicitly requiring in their legislation and regulation that conventional DB actuarial funding valuations must be performed for these plans. Spain recently has identified the problem of DC plans with minimum guarantees ... most of which were created when plan sponsors tried to move away from the complex Spanish regulation of conventional DB plans. Ireland recently has recognized the problem of DC plans retaining the annuity risk. While admitting that there are few such plans in Ireland, it is an explicit recognition of the general issue. The new UK pension reform explicitly addresses the definitions, and the USA has long regulated cash balance plans as defined benefit. The list goes on.

64. EU Pension Fund Directive 2003/43/EC. The two year period for implementation of the directive at the national level in all $25 \mathrm{EU}$ member states has expired, and indeed governments have already taken implementing actions. However, there are still unanswered questions as to the practical meaning in each member state of the requirement in article 16.3 of the directive for cross-border pension plans to be fully funded at all times. The provisions in article 16.2 of the directive setting the basic conditions whereby domestic plans can be underfunded "for a limited period of time" also are still being interpreted. In conjunction with the pension reform concurrently being undertaken in the UK and other EU member states, this has led to some (hopefully temporary) confusion. 
APPENDIX “A”

\section{ACTUARIAL FUNDING METHODS}

65. In the widest possible description of actuarial funding methods, there are up to six very broad categories of financing approaches. However, we can quickly dismiss the two approaches at each extreme. At the minimalist end, there is "pay-as-you-go" and "terminal funding". Pay-as-you-go is a financing method, but not a funding method, as no assets are set aside. Benefits are paid simply when they become due. Under terminal funding, the liability is discharged in full when the employee retires, and usually by the purchase of an annuity from an insurance company. No assets are set aside while the employee is working. At the other extreme, there are two classes of financing that involve heavy pre-funding of future benefits. These approaches also can be ignored. We will now focus on the two important categories of actuarial funding methods, namely:

- Accrued benefit funding methods. These methods focus on maintaining a certain level of funding. They are security driven, in that they attempt to establish and maintain a sound relationship between the fund assets and the accruing liabilities. The funding requirement is then the contributions required to achieve the funding objective. The two most important methods within this category are Current Unit Credit and Projected Unit Credit. Variations included Partially Projected Unit Credit (used in Canada and UK for various purposes) and methods that focus on the assumed termination of the plan.

- Prospective benefit funding methods. In contrast, these methods define a certain level of contributions. They are contribution driven, and the primary objective is stability of such contributions. These contributions then define the targeted level of the fund at any point in time. The three most important methods within this category are Entry Age, Attained Age and Aggregate.

\section{The funding method does not affect the true overall cost.}

66. It is important to remember that the ultimate cost of any pension plan to the plan sponsor is:

Total benefits paid to plan beneficiaries

- Member contributions to the plan

- Investment income earned by the pension fund

+ Expenses incurred in the operation of the plan and the fund.

67. It can readily be seen that there are no actuarial calculations or actuarial estimates in this formula. Nevertheless, because certain actuarial funding methods require higher employer contributions in the early years, which will hopefully result in greater investment income, the eventual employer cost is indirectly affected by the funding method. This is a timing issue, and indeed actuarial funding valuations are all about "timing" - setting aside assets in an organized fashion to discharge the eventual benefit obligations. 
Brief descriptions of each of the main actuarial funding methods will be described, after two brief, but important definitions.

\section{Accrued and Prospective Benefits.}

68. "Accrued benefits" are generally understood to mean pensions-in-payment, deferred pensions of ex-members, and benefits earned by active plan members in respect of accrued pensionable service (service already performed, or years of contribution already made, up to the date of the actuarial valuation). By extension, "prospective benefits" for the third group (the active members) include the effect of projected future service. The treatment of these active members differentiates various funding methods.

\section{Current Unit Credit.}

69. The objective is to maintain a fund equal to the "accrued liabilities", defined as the present value of accrued benefits. Under the Current Unit Credit method, the accrued liabilities for active employees exclude any allowance for the effect of future salary increases. For example, the accrued benefits under a final-average earnings plan generally would be calculated by reference to each employee's current salary. In many cases, the accrued liabilities would approximate the value of the benefits the employee would receive on immediate termination of service or on plan termination. This is a simplistic comparison, but it helps focus the mind on the approximate level of assets the Current Unit Credit method is trying to achieve. The basic contribution for the next year is then (a) the present value of the increase in accrued benefits, primarily the effect of one year's salary increase, plus (b) the present value of the benefits to be earned by the active members because of an additional year of service. The rules of the plan would govern the allocation of this contribution between the employees and the employer.

\section{Projected Unit Credit.}

70. This method is similar to the Current Unit Credit, except that the calculation of the accrued liabilities includes an allowance for the effect of future salary increases on accrued pensionable service and accrued benefits. The normal cost, the so-called "current service cost" or simply "service cost", is then the present value of benefits to be earned by active members because of an additional year of service - as with the accrued liabilities, this service cost includes the predicted effect of future salary increases. There is no second element in the current service cost under the Projected Unit Credit method (cf. the "updating" of accrued liabilities under the Current Unit Credit method), as this is already incorporated into the calculation of the accrued liabilities.

71. This is arguably the most important actuarial funding method, so it is important to understand its fundamental objectives. The goal is to maintain the pension fund assets at such a level that, with future investment income but without any future contributions, the fund will be able to pay all accrued benefits until the last plan beneficiary dies. In this regard, we can think of the plan being suspended, rather than terminated - there are no further contributions and no further accruals of pensionable service, but the plan continues, future salary increases are recognized, and benefits become payable in the normal manner on retirement or prior death, disability or termination of service.

72. The contribution to the fund is then the current service cost plus an adjustment to correct (over an agreed period of time) any imbalance between the accumulated assets and the accrued liabilities. In the event of overfunding, this adjustment is negative. In the event of heavy overfunding, the adjustment matches the current service cost, and a contribution holiday is initiated.

73. It is important to understand that this type of actuarial funding method does not prescribe the amortization of any underfunding or overfunding. It just calculates the accrued liabilities, compares the result with the assets (however valued) and identifies the difference. Any action to correct underfunding or 
take credit for overfunding is then to be discussed. The final decision normally rests with the plan sponsor, after consultation with the trustees, board of foundation or equivalent pension entity. It is at this point that the regulator frequently places constraints on the choices available (see Sections 5 and 6).

\section{Attained Age.}

74. For most plans that provide salary related pension benefits, the future normal funding rate under the Attained Age method is calculated by dividing (a) the present value of all benefits accruing after the valuation date by (b) the present value of future salaries. The normal cost is then obtained by applying this funding rate to the current payroll of the plan members. As these calculations ignore accrued benefits, another calculation is required to compare the accrued liabilities with the accumulated fund assets. The accrued liabilities are calculated in exactly the same manner as under Unit Credit methods, and adjustments to correct any overfunding or underfunding are handled in the same manner. Although the Attained Age method shares some similarities with accrued benefit funding methods, its focus on stability of future normal costs places it in the family of prospective benefit funding methods.

\section{Entry Age.}

75. The normal cost under Entry Age method is the level amount (or the level percentage of pay) that would exactly fund each member's prospective benefits if contributed from the member's date of eligibility until normal retirement date. Unfunded accrued liabilities can exist on the plan's inception date, if the member's pensionable service date precedes the plan's effective date. Otherwise, accrued liabilities at any point in time are simply the present value of prospective benefits over the present value of future normal costs. "Prospective benefits" recognize both accrued pensionable service and projected future service. Note that this definition of accrued liabilities does not correspond in any manner to the present value of accrued benefits described under the accrued benefit funding methods. Future funding contributions are then the Entry Age normal cost plus an adjustment for the difference between accumulated assets and these accrued liabilities.

\section{Aggregate.}

76. For most plans that provide salary related pension benefits, the normal funding rate under the Aggregate Funding method is obtained by subtracting the accumulated fund assets from the present value of all prospective benefits and then dividing the result by the present value of future salaries. The resulting funding rate is then applied to the current payroll of the plan members. "Prospective benefits" recognize both accrued pensionable service and projected future service. There is no unfunded liability under this approach, as all experience gains and losses are absorbed into the single calculation. In effect, they are amortized through to retirement age. There is a common misconception that the Aggregate method generates conservative funding. This is generally true if the plan experience conforms with the actuary's assumptions. It is certainly true if the plan experience is favourable, because the process of taking credit for the funding excesses is extremely slow (right through to retirement age). However, if a plan is underfunded in a conventional sense, then it will stay underfunded for a long time - again, because of the slow amortization implicit in the method.

\section{SAMPLE CALCULATIONS}

77. Simple illustrations of the fundamental differences between the calculations of the funding rates under four of the above actuarial funding methods will now be provided. The same asset value is used in all cases. This common starting point helps to highlight the effects of moving forward with each of the different funding methods. In reality, if each funding method had been followed in the past, the contributions to the pension fund - and the resultant accumulation of the assets - would have been different. 


\begin{tabular}{|l|r|c|c|c|c|}
\hline (PV = present value) & Value & CUC & PUC & AttAge & AGG \\
\hline Assets in the pension fund & 120 & Yes & Yes & Yes & Yes \\
\hline \begin{tabular}{l|l|l|l|} 
\\
PV of accrued benefits (current salaries)
\end{tabular} & 80 & Yes & & & \\
\hline PV of benefits accrued one year from now & 88 & Yes & & & \\
\hline $\begin{array}{l}\text { PV of one year's benefits (projected salaries) } \\
\text { i.e. (current) service cost under PUC method }\end{array}$ & 11 & & Yes & & \\
\hline $\begin{array}{l}\text { PV of accrued benefits (projected salaries) } \\
\text { PV of future benefits (projected salaries) }\end{array}$ & 150 & & Yes & Yes & Yes \\
\hline PV of total projected benefits (150 + 130) & 130 & & & Yes & Yes \\
\hline PV of future salaries & 280 & & & & Yes \\
\hline
\end{tabular}

\section{Abbreviations:}

$\checkmark$ CUC: Current Unit Credit actuarial funding method.

$\checkmark$ PUC: Projected Unit Credit actuarial funding method.*AttAge: Attained Age actuarial funding method.

$\checkmark$ AGG: Aggregate actuarial funding method.

\section{Current Unit Credit:}

- $\quad$ Basic contribution $=88-80=\mathbf{8}$.

- But, there is a funding excess of 40 (120 assets - 80 liabilities) that can be applied to reduce contributions.

\section{Projected Unit Credit:}

- $\quad$ Basic contribution $=$ Service Cost $=11=\mathbf{1 0 . 0 \%}$ of payroll.

- But, there also is a funding shortfall of 30 (150 liabilities - 120 assets) that will need to be addressed. For example, by being amortized over the next five years.

\section{Attained Age:}

- $\quad$ Future funding rate $=130$ divided by $1,000=\mathbf{1 3 . 0 \%}$ of payroll, so contribution $=14.3$.

- But, there also is a funding shortfall of 30 (150 liabilities -120 assets) that will need to be addressed. For example, by being amortized over the next five years.

\section{Aggregate:}

- Funding rate $=(280$ total liabilities -120 assets $) \div 1,000=\mathbf{1 6 . 0 \%}$ of payroll $=17.6$. 


\section{APPENDIX "B"}

\section{PENSION PLAN FUNDING REGULATIONS}

78. Occupational defined benefit pension plans financed through autonomous pension funds are to be found in all of the countries analyzed in this Appendix. In summary:

1. Employers or group of employers can establish occupational plans where they bear the risk for a certain benefit formula or lump-sum benefit (generally based on salary and service), or the higher of a defined benefit and a defined contribution pension;

2. Plan sponsors are permitted or required to establish autonomous pension funds as a means of financing the obligations created under such a pension plan; and

3. Plan sponsors are permitted or required to establish pension entities (e.g. trust, foundation, corporate entities) that own and may control the autonomous pension fund on behalf of plan members

79. Although these countries also permit other financing arrangements, such as insurance contracts, the individual country summaries in this Appendix focus on the different regulatory approaches taken by the tax and supervisory authorities to the funding of defined benefit pension plans using autonomous pension funds. 


\section{AUSTRIA}

\section{Supervisory Control.}

80. The 1990 Company Pensions Act (BPG) authorizes four different financing arrangements for company pension plans and also establishes minimum vesting, portability and other requirements. Three of the financing arrangements (book reserves, support funds and direct insurance) are not relevant to this report. The fourth is a Pensionskasse (Pensionskassen, in the plural), which is a special form of pension fund. Around half of company pension plans in Austria are financed by book reserves, over one third by pension funds and the rest by insurance contracts. The 1990 Pension Fund Act (PKG) regulates the establishment, operation and supervision of single and multi-employer pension funds, as well as laying down rules concerning asset management, minimum funding and accounting. The Financial Market Authority (FMA) supervises pension funds, insurance companies and other financial service providers. The funding rules for pension funds (pensionskassen) will be discussed below.

\section{Minimum Funding Requirements.}

81. The basic objective of the minimum funding requirements is for the fund assets to exceed the sum of the accrued liabilities and a contingency fund.

For these purposes:

- Assets are taken at fair market value.

- The only permitted actuarial costing methods are those that recognize the liabilities over the active service life of each plan member (current unit credit, individual entry age, attained age).

- The liabilities to be funded include the full value of pensions in payment and deferred pensions.

- The maximum discount rate for calculating the liabilities is between $3.0 \%$ and $6.5 \%$, depending on the date of creation of the fund and the form of benefit indexation.

82. The maximum period for correcting any underfunding resulting from plan experience differing from the actuarial assumptions is ten years. All other underfunding must be corrected immediately.

83. In order to compensate for potential investment losses, every Austrian pension fund must establish a contingency or volatility reserve ("Schwankungsrueckstellung"), designed to equalize profits and losses from the investment of the assets and from the technical account balance. The mechanism for calculating the "contingency reserve" is described in detail in the Austrian Pension Companies Act (PKG); it can range from a maximum of $20 \%$ to a minimum of $-5 \%$ of assets, and operates according to boundaries. The targeted value for the "volatility reserve" is between $10-15 \%$ of pension liabilities, and it must be financed from employer contributions. If the volatility reserve exceeds this target value, $10 \%$ of the excess shall be immediately released (with the management board allowed to determine exceptions). The upper boundary is $20 \%$. If the volatility reserve exceeds $20 \%$ of the allocated assets, these are released to the extent of the difference. In terms of the lower boundary, if the application of the reserve rules results in a negative volatility reserve, the reserve for future beneficiaries is immediately released in full. For plan members who have already retired or are receiving benefits, only the part of the negative reserve exceeding $5 \%$ of allocated assets is immediately released. 


\section{Customary funding practices.}

84. Customary funding practice is prescribed in the pension fund contract and in accordance with the collective agreement or equivalent document. As multi-employer Austrian pension funds can cover a wide variety of plans, there also can be a variety of actuarial methods involved in calculating liabilities and contributions. The most commonly used include the following:

- Most pension companies use the attained age method to calculate liabilities and contributions. The underlying assets are recognized at their market value smoothed by the contingency reserve.

- The individual entry age method is not commonly used to calculate annual contributions, but it is often used to calculate initial transfer amounts when changing an unfunded, book-reserved plan into a plan financed by a pensionskasse. In some cases, the calculated transfer amounts are increased by an initial contingency reserve.

- The projected unit credit method is used primarily by pension funds established by large companies that are members of a multinational group.

- The discount rate used to calculate liabilities depends mainly on the benefit-increases (indexation) prescribed in the plan rules; the rate varies from 3.5-6.5\%. Explicit allowances for salary increases are only made when they are not implicitly recognized in the discount rate; they range from $2 \%$ $5 \%$ and in some cases depend on age and/or years of service. Similarly, explicit allowances for benefit indexation are only made when they are not implicitly recognized in the net discount rate; they range from $1 \%-4 \%$, depending on the plan. Turnover assumptions are not included.

- Demographic assumptions can be chosen by the actuary. In 1999, a new set of generational mortality tables was published by the Austrian Association of Actuaries (AVÖ). There are different tables for 'white-collar employees' only and 'mixed white-collar and blue-collar employees'. These new tables are generally used when calculating book reserves and have been used for almost all pension fund calculations since 2001. In some cases, the tables published in 1989 (which are for 'mixed white-collar and blue-collar employees' and do not include any generational allowance for improving mortality) are still used.

\section{Maximum funding limits.}

85. From a pension law perspective, there are no maximum funding limitations. However, tax law specifies several maximum limits for both defined benefit and defined contribution plans.

\section{Frequency of actuarial valuations.}

86. A report by an independent external actuary must be prepared annually and submitted to the Financial Market Authority (FMA).

\section{Bankruptcy of plan sponsor.}

87. In the case of the bankruptcy of the plan sponsor, the fund assets belong to the plan members. There is no possibility of a refund of surplus assets to the bankrupt plan sponsor. Correspondingly, further creditors rights do not exist. There is no mandatory insolvency insurance program, and the plan sponsor is not required to insure the pension rights of the members. 


\section{Termination of an overfunded plan.}

88. In general, the surplus assets belong to the risk sharing group and go into technical account balance. Depending on the individual claims, the surplus is distributed to the members of the risk sharing group.

\section{Who appoints the actuary?}

89. The pension fund appoints the actuary. The appointment of a member of the pension fund board as an actuarial expert must be approved by the supervisory board. In addition, the pension fund must appoint an independent external actuary to conduct the annual actuarial audit; this appointment also must be approved by the supervisory board. Actuaries must have proven proficiency in the field of actuarial analysis, and external actuaries must be independent (defined as not receiving more than $30 \%$ of yearly income from, and not carrying out any other function for, the pension fund). The appointment of both employed actuaries and external actuaries must be notified to the FMA, which may disapprove of the appointment within one month.

\section{Role of the actuary.}

90. The independent external actuary must monitor compliance with the pension fund's "business plan": examining whether the business plan is being correctly implemented; whether any changes to the current contribution rates or benefit structure are necessary; whether any funding shortfall exists; and whether and to what extent and by what deadline the employer has to address any such underfunding. The actuary has to exercise his activity with due regard to the statutory provisions relevant to his activity as well as all technical standards in accordance with recognized actuarial principles.

91. A pension fund must prepare the aforementioned business plan outlining its actuarial and technical provisions. The business plan must be reviewed by an independent external actuary and approved by the FMA. The business plan contains any and all details and parameters required for the operation of the pension fund, in particular:

- the types of benefits offered:

- the presentation of the circumstances which are significant for the safeguarding of the interests of the beneficiaries and for assessment of continued compliance with the pension fund's obligations;

- the bases of calculation (mortality tables, economic assumptions, assumed discount rate, expense loadings, targeted technical surplus);

- the type and management of the volatility reserve;

- the investment policy, as well as the method for apportioning the assets of a multi-employer fund between the various plans and the various groups of beneficiaries;

- the principles of, and the formulas for, calculating the plan sponsor contributions. 


\section{BELGIUM}

\section{Supervisory Control.}

92. There are specific minimum funding requirements in Belgium. These requirements are established by government regulation, in particular a Royal Decree of 7 May 2000, and administered by the insurance supervisory authorities (l'Office de Contrôle des Assurances in French, and Controledienst voor Verzekeringen in Dutch). Customary funding practices are established by the actuarial profession. There are no direct maximum funding requirements.

\section{Minimum Funding Requirements.}

93. Under the minimum funding requirements, fund assets must equal or exceed the sum of the following:

- accrued liabilities; plus

- if the plan provides disability and death-in-service benefits, an additional solvency margin.

For these purposes:

- Accrued benefits equal the highest of (i) the vested rights as defined in the plan rules, (ii) the past service benefits based on current salaries, and (iii) the employee's own contributions accumulated with interest.

- The accrued liabilities are valued using the current unit credit method.

- The maximum discount rate is $6 \%$ pa.

- The mortality tables are specified by the authorities, namely the MR 88-90 table for males and the FR 88-90 table for females.

- No assumptions are permitted regarding employee turnover,

- Pensions are assumed to commence at normal retirement age, although an adjustment must be made for plans that provide subsidized early retirement benefits.

- Special rules apply to a pension funds that supplement group insurance contracts (a common arrangement in Belgium, generally with employee contributions going to the insurance contract).

- The additional solvency margin for death and disability benefits is a complicated function of total sums at risk, the five largest sums at risk, etc... If all or a portion of the death and disability benefits are reinsured, the solvency margin may be reduced proportionately, but not to below $50 \%$ of the full solvency margin.

- Assets are taken at fair market value. 
94. In the event of a shortfall (assets less than accrued liabilities):

- A plan to liquidate the shortfall must be submitted to, and approved by, the regulator.

- The effect of an increase in liabilities caused by the Royal Decree of 7 May 2000 or by any subsequent modifications of the minimum standard can be amortized over as long as 20 years.

- There are severe penalties for plan sponsors that fail to comply with the agreed financing plan.

\section{Customary funding practices.}

95. There are no government constraints in this area.

96. However, the following observations can be made:

- The most common actuarial valuation methods are Projected Unit Credit and Aggregate.

- It would be normal to use the same MR and FR mortality tables as are specified for the minimum funding test.

- Otherwise, the economic and demographic assumptions are established by the actuary in accordance with standard actuarial practices.

- Disability and death-in-service benefits may be insured, in which case the annual insurance premium will be added to the current service cost for the retirement benefits. Even if these benefits are not (re)insured, the actuary may still cost them on an annual "risk premium" basis.

- The minimum funding requirement is a funding constraint, rather than a funding objective.

- Fund assets are usually taken at market value.

- These valuations serve as the basis for claiming employer tax deductions.

\section{Maximum funding limits.}

97. There are no direct limits on the maximum amount of assets that can be held in a pension fund.

98. However, there are two indirect constraints:

- The maximum pension that can be provided under a tax-effective Belgian pension plan is $80 \%$ of final salary - after a full career, and inclusive of social security benefits.

- The "financing plan" prepared by the actuary and submitted to the insurance control authorities must take account of the $80 \%$ limit.

99. The financing plan must take into account any overfunding when developing its future funding costs. There are no requirements to suspend contributions until the funding excess is exhausted, but the financing plan must address the overfunding in a systematic manner; the regulator takes a dim view of dramatic changes in financing plans. The plan sponsor is not allowed to withdraw excess assets from the fund, so that is not an option. 
OECD Working Paper on Insurance and Private Pensions

\section{Frequency of actuarial valuations.}

100. Valuations are required to be performed annually.

\section{Bankruptcy of plan sponsor.}

101. Whether the plan is overfunded or underfunded, the entire assets of the fund are allocated between the plan members. There is no government insurance program to cover shortfalls.

\section{Termination of an overfunded plan.}

102. The entire assets are allocated between the plan members. In other words, each plan member receives an appropriate share of the funding excess. As already indicated, there are no circumstances under which excess assets can revert to the plan sponsor.

\section{Who appoints the actuary?}

103. The actuary is appointed by the pension fund. He or she must hold a European degree in actuarial sciences and must have relevant experience over a period exceeding five years.

\section{Role of the actuary.}

104. The appointed actuary has to advise on the financing of the plan, the reinsurance arrangements and the calculation of the technical provisions. 


\section{BRAZIL}

\section{Supervisory Control.}

105. Funding requirements are described in detail in Complementary Law 109/01 of 30 May 2001 and associated regulations. Complementary Law 108/01 describes additional requirements for pension plans sponsored by public companies. Different supervisory regimes apply to closed funds (covering a single employer or group of companies, an association or a union) and open funds (insurance company and similar products available to both individuals and employers). The legislation covering closed funds is of more direct relevance to this report. Closed pension funds are supervised by the Secretaria de Previdencia Complementar (SPC), reporting to the Ministry of Social Security and Assistance. Regulations are issued by the Conselho de Gestão de Previdência Complementar (CGPC), a special board comprised of heads of the SPC and the social security administration, together with representatives from other ministries and from pension fund associations. Open pension funds are supervised by the Superintendencia de Seguros Privados (SUSEP), reporting to the Ministry of Finance.

\section{Minimum Funding Requirements.}

106. Article 18.3 of the aforementioned Pension Law 109/01 states that "accumulated assets of each benefit plan must at all times fully cover existing obligations under the plan". This statement has caused considerable confusion within the industry, and a clear interpretation of its meaning is still being sought. In the meantime, CGPC/MPAS Resolution $\mathrm{n}^{\circ} 11$ of 21 August 2002 provides the basic guidance on actuarial funding issues. The rules regarding minimum funding can be summarized as:

- Liabilities shall be calculated using the current unit credit actuarial costing method applied to the closed group of existing plan members and beneficiaries.

- Accrued benefits are to be calculated using historical salaries, i.e. without future projections.

- The real discount rate cannot exceed 6\% pa.

- The AT 49 mortality table must be used. There are already active discussions on replacing this mortality table with a table more up-to-date and appropriate to the Brazilian working population.

- The employee turnover assumption cannot exceed 5\% per year, unless a higher rate can be justified by the plan sponsor.

- Disability and survivor pensions can be financed on a terminal funding basis, whereby the entire liability is funded at the time of the death or commencement of disability benefits. Death and disability lump sums can be financed on a pay-as-you-go basis.

- Alternatively, such death and disability benefits can be reinsured (CGPC/MPS Resolution $n^{\circ} 11$ of 27 May 2004).

107. The maximum period for correcting any underfunding of the liabilities for active members is the weighted average future working lifetime. The maximum period for correcting any underfunding of pensioner liabilities is the weighted average life expectancy. These provisions closely follow the methodology in North American and international accounting standards. 


\section{Customary funding practices.}

108. Any actuarial funding method is permitted, as long as it generates contribution requirements that equal or exceed the minimum funding requirements. Current Unit Credit is widely used, although Projected Unit Credit and Aggregate also are to be found. Under Resolution CGPC/MPAS $\mathrm{n}^{\circ} 3$ of 19 December 2001, an independent actuarial audit must be completed at least every five years and the conclusions submitted to the SPC. The requirements of such an audit are extremely rigorous.

\section{Maximum funding limits.}

109. Article 20 of Pension Law 109/01 directly addresses the issue of maximum funding. Basically, plan sponsors are allowed to establish a contingency reserve of up to $25 \%$ of the accrued liabilities. For these purposes, the accrued liabilities are calculated under the funding method used for customary funding. The implication is that plan sponsors desiring faster or conservative funding of their obligations should use the projected unit credit or aggregate funding method. However, there must be a consistency of approach from one year to the next. Any fund assets beyond the $25 \%$ limit then constitute a special reserve. This special reserve can be maintained for three years, or it can be used in the interim for benefit improvements or contribution reductions. If there is a positive balance in the special reserve for three consecutive years, then it must be spent on benefit improvements or used to reduce both employee and employer contributions.

\section{Frequency of actuarial valuations.}

110. Valuations are required to be performed annually.

\section{Bankruptcy of plan sponsor.}

111. Whether the plan is overfunded or underfunded, the entire assets of the fund are allocated between the plan members. There is no government insurance program to cover shortfalls.

\section{Termination of an overfunded plan.}

112. The entire assets are allocated between the plan members. In other words, each plan member receives an appropriate share of the funding excess.

\section{Who appoints the actuary?}

113. The pension fund appoints the actuary.

\section{Role of the actuary.}

114. The actuary provides advice on the sound funding of the plan, including the minimum funding requirements, and provides most of the input for the actuarial report that must be submitted each year by the pension fund to the regulator (the SPC). 


\section{CANADA}

\section{Supervisory Control.}

115. The division of responsibilities between the federal government and the various provincial governments complicates the pension supervisory structure in Canada. Except for a relatively small percentage of workers who are governed by federal employment legislation, it is the role of the provinces to regulate pension plans and set standards in all the traditional areas such as minimum vesting, disclosure, minimum funding, etc... Federal and provincial pension law in Canada is harmonized through the Canadian Association of Pension Supervisory Authorities (CAPSA). In general, CAPSA may propose changes to existing pension legislation and regulations, though it must receive Ministerial approval. Of necessity, this paper will make generalizations concerning the various minimum funding standards, but this should not distract from the basic conclusions. Through CAPSA and through its close liaison with the Canadian Institute of Actuaries (CIA), there is considerable consistency of approach.

116. The federal government controls the maximum amount of funding in defined benefit pension plans through limits, set out in the federal income tax rules, on the type and level of benefits that such plans may provide, and on the amount of surplus that a pension plan may hold.

117. Customary funding practices are established by the actuarial profession.

\section{Legislation and consultation in 2005.}

118. In 2005, there were several important initiatives by legislators and the actuarial profession regarding further improvements to the funding (and the regulation of the funding) of defined benefit pension plans.

119. These initiatives included:

- Quebec Bill 102 concerning (i) a temporary relaxation of the minimum funding requirements, (ii) authorizing the use of letters-of-credit and (iii) severely restricting plan improvements by underfunded plans (5 May). Details are provided below.

- Quebec working paper on "towards better funding of defined benefit plans" (24 May). Builds on the temporary measures in Bill 102.

- Federal consultation paper on "strengthening the legislative and regulatory framework for defined benefit pension plans registered under the Pension Benefits Standards Act" (May). In a similar vein to the Quebec legislation and working paper. Of particular interest is the request for input on the controversial subjects of disincentives and obstacles to adequate funding or overfunding of pension plan liabilities, the ownership of surplus assets and related matters.

- CAPSA discussion paper on "proposed funding principles for a model pension law" (20 June). A more technical paper that primarily transforms current common provincial and federal funding regulations into a single model. Of particular interest is its stated objective that "A funding requirement should provide appropriate assurance that sufficient plan assets are maintained to deliver the promised benefits in defined benefit plans, particularly in the situation of employer bankruptcy". In other words, full funding at all times is neither required nor realistic. 
- Canadian Institute of Actuaries "statement on revised actuarial standards of practice for reporting on pension plan funding" (March). For going concern valuations, the paper discusses "unbiased measurement" of assets (market value) and liabilities (best estimate assumptions) and then describes explicit "provisions for adverse deviations" (contingency reserves) and "adjustments to unbiased measurements" (positive or negative adjustments, such as asset value smoothing).

120. All except the CAPSA paper talk about (a) a possible relaxation of solvency funding requirements, (b) alternative financial instruments such as letters-of-credit, (c) severe restrictions on making benefit improvements to underfunded plans and (d) reform of the current 'asymmetrical' surplus ownership rules.

\section{Minimum Funding Requirements (solvency basis).}

121. Each supervisor requires minimum funding sufficient to provide the accrued vested benefits to which the members would be entitled in the event of plan termination. For these purposes:

- Solvency valuation, as defined, means a valuation of the assets and liabilities of a plan using actuarial assumptions and methods that are in accordance with accepted actuarial practice for the valuation of a plan, determined on the basis that the plan is terminated at the valuation date.

- Assets are taken at market value, although some supervisors will allow a smoothing method over up to five years, if a smoothing method over the same time period also is used for the initial interest assumption in the valuation of the liabilities. Alternatively, this smoothing alternative generally is allowed when the plan is experiencing problems because of poor investment performance or when there has been a rapid drop in interest rates.

- The accrued liabilities are valued using the accrued liability (current unit credit) method.

- Most supervisors require the actuary to make assumptions concerning the proportion of members who would elect a commuted value (and transfer from the plan) and the remainder who would leave their deferred or immediate pension benefits in the plan. In turn, the commuted value normally must assume the most advantageous early retirement date provided by the plan for terminated members. For older or long service employees $($ age + service $=55$ years $)$, some supervisors require the commuted value to be determined assuming the active member will remain active and will retire at the most advantageous early retirement date for active members. Note early retirement is an important issue under most union and many other Canadian pension plans.

- When calculating commuted values, the actuary must follow a Standard of Practice prescribed by the CIA. This standard currently prescribes the UP-94 mortality table projected forward to the year 2015 using mortality projection scale AA, no pre-retirement mortality or other decrement, and an interest rate of $x \%$ per annum for 10 years and $y \%$ per annum thereafter. The rate " $x$ " is equal to the market yield on 7-year Government of Canada benchmark bonds plus $0.5 \%$. The rate " $y$ " is a more complicated blend of market yields on such 7-year bonds and on long term Government of Canada benchmark bonds, again plus $0.5 \%$. Lower interest rates apply when the plan provides indexation of pensions; the formulas are specified in the CIA Standard of Practice.

- Proxy assumptions for annuity purchases from an insurance company would be used for the members who are assumed to retain their benefits within the plan.

- Some regulators require unisex mortality; others require sex-distinct mortality. 
122. Any shortfall (assets less than accrued liabilities) revealed in an actuarial valuation must be eliminated within five years. Each shortfall has its own five-year amortization schedule, so new shortfalls discovered in subsequent valuations involve new five-year amortizations, whilst the earlier amortization schedules are continued until they expire.

123. Under Quebec Bill 102 of 5 May 2005, the minimum funding requirements have been relaxed (temporarily) for Quebec-registered plans. As a first step, all existing solvency deficits can be aggregated and re-amortized over five years. Subject to certain conditions, the payments in the first five years can be calculated as if a ten-year amortization period had been adopted; the balance at the end of the five years is then re-amortized in the conventional manner. This second approach is available only if: (a) the plan sponsor is a municipality, a university or an education institution at the university level; or (b) both the active and inactive members give their consent (which is deemed to be given unless $30 \%$ of one group or the other explicitly objects); or (c) the plan sponsor provides a guarantee (e.g. a letter-of-credit). The idea of employing letters-of-credit is discussed in further and more general detail in Section 7 of this report. Plan amendments that create immediate unfunded liabilities will not be allowed during the application of the second approach, unless such additional liabilities are fully and immediately funded.

\section{Customary funding practices (and minimum funding on a going concern basis).}

124. Regulations typically require actuarial valuations to follow the professional requirements of the Canadian Institute of Actuaries. The regulations also include minimum funding requirements calling for funding of unfunded liabilities and solvency deficiencies over specified periods.

- Going concern valuation, as is defined in the regulations, means a valuation of the assets and liabilities of a plan using actuarial assumptions and methods that are in accordance with accepted actuarial practice for the valuation of a plan, assuming that the plan will continue to operate indefinitely. The assumptions and methods are selected by the actuary and normally include margins for adverse deviations.

- The most common actuarial valuation method for final average salary plans is, and always has been, the Projected Unit Credit. The Current Unit Credit method generally is used for flat benefit and career average earnings plans.

- None of the actuarial assumptions is prescribed, although a supervisor will question the actuary about the appropriateness of high interest rates or old mortality tables (previous to GAM 1983).

- Assets can be taken at current market value or smoothed over a period not exceeding five years. The smoothing method is losing favor, perhaps because of concern about pension expensing (accounting) standards.

- Most supervisors will allow the funding of any going-concern experience deficiency or other unfunded liability (e.g. retroactive plan improvements) over a period not exceeding 15 years.

125. In accordance with the proposed minimum funding target highlighted in the January 2003 "Final Report of the CIA Task Force on Pension Plan Funding", the minimum funding target should be achieved within five years of solvency funding (item 5 above) plus a margin; guidelines are provided to help the actuary establish the appropriate margin. It is important to note that the proposed minimum funding target has not yet been approved. In effect, the Partially Projected Unit Credit method is used, in that salaries, etc... are projected for the five-year period, but not beyond. 


\section{Maximum funding limits.}

126. Under the federal income tax rules, which are administered by the Canada Customs and Revenue Agency (CCRA), "full funding" is permitted on either the customary funding basis, with methods and assumptions determined by the actuary (item 6 above), or on the solvency basis, with assumptions and methods prescribed by the supervisors (item 5 above). There are then specific limits on the amount of any "funding excess" or surplus. An actuarial surplus can be retained or otherwise ignored to the extent it does not exceed the lesser of:

- $20 \%$ of the actuarial liabilities; and

- the greater of $10 \%$ of the accrued liabilities and twice the combined employee/employer current service costs for the first year following the valuation.

127. Effectively, for a mature plan with many pensioners and few active employees, the surplus cannot exceed $10 \%$ of accrued liabilities. For a relatively immature plan, the limit is the lesser of $20 \%$ of liabilities and two years' current service costs. An important aspect is that the government does not prescribe the actuarial method or assumptions, so the actuary can introduce stability into the funding exercise by smoothing the asset values, etc... In effect, this establishes investment reserves when the market is temporarily bullish and smoothes the effects of downturns.

128. In the event of surplus in excess of the above limits, the employer must stop its contributions to the pension fund. Employee contributions are permitted to continue. In lieu of an employer contribution holiday, the plan sponsor could amend the plan to provide enhanced benefits such as ad hoc indexing for pensioners, formalized future indexing, or enhanced early retirement provisions. However, enhancing benefits based on what may be a temporary surplus would have to be assessed against the long-term funding implications. Furthermore, retroactive increases in the basic benefit or basic accrual rate can be complicated by the immediate tax impacts on plan members.

129. The Government of Canada has recently proposed a change for plans where funding shortfalls and excesses are shared equally between the employer and the employees (fixed cost-shared plans). In a fixed cost-shared plan, an employer contribution holiday automatically triggers a corresponding employee contribution holiday. The proposed change will allow employee and employer contributions under such plans to continue to be made when there is a funding excess of between 10 per cent and 25 per cent of accrued liabilities. The contributions would be calculated as a declining percentage of the normal annual pension costs. The change will put these plans on a more equal footing with traditional defined benefit plans for which employee contributions may continue regardless of the amount of surplus.

130. Under most pension regimes, it is difficult for an employer to recover surplus assets from the fund in an ongoing situation without the approval of virtually all the members - even when the plan provisions state that the employer owns the surplus!

131. Irrespective of the limits on funding excesses contained in the tax rules, it is important to remember that there is little incentive for overfunding of medium and large scale Canadian pension plans because of the uncertainties regarding surplus ownership. If the employer is fully responsible for deficits, and if the employees are the full or primary beneficiaries of overfunding, then the result is inevitable. Some employers will simply take all possible measures to avoid any overfunding in the first place. Nonetheless, the surplus limits are required to prevent overfunding that could arise from other considerations. In particular, for smaller defined benefit plans where the interests of the plan members and the employer may be one and the same, the limits on excess surplus are key to preventing excessive deferrals of tax that could otherwise be achieved through deliberate overfunding. 


\section{Frequency of actuarial valuations.}

132. Valuations are required to be performed every three years. However, the federal regulator (the Office of the Superintendent of Financial Institutions) and one provincial regulator (Ontario) require annual valuations if the solvency ratio (see item 5) is less than $100 \%$ and $80 \%$ respectively.

\section{Bankruptcy of plan sponsor.}

133. Creditor rights of plan members fall behind numerous other secured lenders. Only Ontario provides a guarantee fund (the PBGF) in the event of plan sponsor insolvency, and then only for single employer plans. These single employer plans must pay an annual assessment fee to the PBGF, based on the number of plan members and any (solvency basis) unfunded liability.

\section{Termination of an overfunded plan.}

134. Surplus funds usually are applied to provide extra plan benefits to members. Any surplus paid to members in cash usually would be allocated in proportion to each member's accrued liabilities. In some jurisdictions an employer may access surplus on plan wind-up, subject to obtaining the consent of at least two-thirds of members, former members and other persons within prescribed categories, and if the prescribed funding margins have been satisfied. If fewer than two-thirds but more than one-half of each category consent, legislation in some jurisdictions allows the employer to go to binding arbitration. All funds dispersed are treated as income to the members or to the employer in the year received, and they are taxed accordingly. No special, additional taxes apply.

\section{Who appoints the actuary?}

135. Each pension plan must have an "administrator" which bears ultimate responsibility for the plan. This administrator is either the plan sponsor or a board of trustees. The administrator then appoints the actuary and other professionals who are required for the smooth operation of the plan.

\section{Role of the actuary.}

136. The current and future role of the pension actuary is a topic of ongoing discussion within the profession. Basically, the actuary acts as a pension consultant to the administrator. The actuary is expected to prepare a valuation report using assumptions and methods which provide some contribution flexibility for the employer, but which ensures that the pension fund eventually will protect the future interests of the plan members. However, the actuary is not (and does not want to be) a plan fiduciary. The actuary can recommend certain actions to the administrator but cannot compel the administrator to act. An actuary sometimes may feel compelled to resign, and the supervisor may require an explanation from the administrator concerning any change of actuary. 


\section{IRELAND}

\section{Supervisory Control.}

137. Minimum funding requirements are established under the Pensions Act. The Social Welfare and Pensions Bill 2005 introduced considerable changes to the Pensions Act, some provisions of which affected the minimum funding requirements. The supervision of pension plans and pension funds is carried out by the Irish Pensions Board. Customary funding practices are established by the actuarial profession.

\section{Minimum Funding Requirements.}

138. The basic objective of the minimum funding requirements (the so-called Funding Standard) is for the assets to at least equal the accrued liabilities. The Pensions Act prescribes the use of a plan discontinuance basis, but it does not prescribe all the detailed assumptions to be used. In practice, the actuary must conduct such valuations in accordance with professional guidance issued by the Society of Actuaries in Ireland. The applicable guidance notes are GN3, GN3A and GN9. Highlights include:

- Fund assets are to be taken at realisable value, i.e. fair market value less selling costs.

- In respect of pensions in payment, the actuarial basis should be consistent with the cost of buying matching annuities in the marketplace. In respect of non-retired members, the value shall be no less than the sum of the individual transfer values to which each member would be entitled under the standard transfer value basis contained in Guidance Note 11 issued by the Society.

- Allowance must be made for the estimated expenses of winding up the plan.

139. In the event of the fund assets being less than the discontinuance liabilities, the shortfall normally must be liquidated within 3 years (but see next paragraph).

140. The Social Welfare (Miscellaneous Provisions) Act, 2003 amended the Pensions Act to give additional flexibility to the Pensions Board in its administration of the Funding Standard. These somewhat temporary provisions were consolidated and expanded in the Social Welfare and Pensions Bill 2005. As a result, the Pensions Board now has the power to extend the three year period for correcting a shortfall to as much as ten years (or even longer) if certain conditions are met. These include:

- the shortfall was due to adverse experience resulting from (a) an exceptional fall in the value of markets, (b) a sharp drop in the interest rates used to calculate liabilities, (c) unusual price inflation or salary increases or (d) payment or early retirement and similar enhanced benefits.

- the actuary's reasonable expectations as to the return on the fund assets, as well as other elements of the plan's experience, would show that the plan could reasonably be expected to fully satisfy the funding standard within the agreed period;

- the proposed funding contributions are weighted to ensure a funding level of at least $85 \%$ of the discontinuance liabilities within three years of the effective date of the funding proposal; and

- the trustees inform the plan members of the new funding proposal. 


\section{Customary funding practices.}

141. The actuary conducts regular funding valuations and produces actuarial valuation reports in compliance with a number of Guidance Notes issued by the Society of Actuaries in Ireland; these include GN3, GN3A, GN9 and GN11. The Pensions Act requires actuarial valuations to be prepared every three years. The most common actuarial funding method is the Projected Unit Credit, although Attained Age and Aggregate methods are still to be found. The actuary has wide discretion in setting the assumptions used to calculate the liabilities. Assets are usually taken at fair market value or smoothed market value.

\section{Maximum funding limits.}

142. There are no direct quantitative limits concerning the maximum amount of assets that can be held in a pension fund. There are procedures to prevent abuse, although they rarely are applied. The tax authorities require that the matter be brought to their attention when a valuation discloses a surplus in excess of $10 \%$ the liabilities, with assets and liabilities being valued under the chosen method.

\section{Frequency of actuarial valuations.}

143. Full actuarial valuations are required to be performed at least every 3 years. The traditional $3 \frac{1}{2}$ year period was reduced in 2005 to 3 years, in line with the EU pension fund directive. Actuarial reviews now must be carried out between full valuations in order to establish whether the plan continues to satisfy the Funding Standard. If a positive statement cannot be made in this regard, then an actuarial funding certificate must be prepared.

\section{Bankruptcy of plan sponsor.}

144. In the event of the wind up of a defined benefit plan in any circumstances, an order of priorities for allocating the assets is prescribed in Section 48 of the Pensions Act, namely: (a) expenses associated with the wind-up; (b) benefits arising from additional voluntary contributions, including AVCs forming part of any transfer payment received; (c) pensions-in-payment, excluding future discretionary increases in such pensions; (d) benefits in respect of "reckonable service" (as defined in the law), together with revaluation of post-1991 preserved benefits and benefits generated by transfer payments received; (e) revaluation of pre-1991 preserved benefits and any uplift to provide minimum contributory benefit for members entitled to an immediate retirement benefit at the date of plan windup; and (f) any other benefits in accordance with the priorities specified in the plan rules.

\section{Termination of an overfunded plan.}

145. The fund assets first would be allocated in accordance with the priorities prescribed in the Pension Act (see previous paragraph), and then in accordance with the priorities in the plan rules. If there are still excess assets, and if the plan rules so provide, such assets can be refunded to the plan sponsor.

\section{Who appoints the actuary?}

146. The Irish equivalent of the "pension entity" in OECD parlance is the board of trustees. The trustees appoint the plan actuary. In order to sign an Actuarial Funding Certificate for the purposes of the Pensions Act, the actuary must be a Fellow of the Society of Actuaries in Ireland who has been granted and holds a valid pension plan actuary practising certificate under the rules of the society. 


\section{Roles of the actuary.}

147. The appointed actuary is required to conduct regular actuarial valuations, inter-valuation reviews, prepare Actuarial Funding Certificates and assist in the development of Funding Proposals for addressing any underfunding.

148. Specifically:

- The actuary must certify that the funding proposal being submitted to the Pensions Board meet the requirements set out in the Pensions Act.

- The actuary must certify the reasons for the failure of the plan to meet the minimum funding standard.

- The actuary must prepare a prescribed statement (certificate) for the plan's annual report.

149. It should be noted that actuarial certificates also are required from defined contribution plans that pay pensions from fund assets, rather than buying annuities from an insurance company. This requirement was introduced in the Social Welfare and Pensions Bill 2005. Although it is expected only to affect a very small number of plans in Ireland, it serves to identify an issue that needs to be addressed, or may eventually need to be addressed, in other countries. 


\section{JAPAN}

\section{Supervisory Control.}

150. Pension plans are supervised by the Ministry of Health, Labor and Welfare (MHLW). Plans are also subject to rules and regulations set by the Tax Administration Authority.

151. As a result of the Pension Reform that became effective in April 2002, there are now several financing arrangements for defined benefit pension plans. In this context, defined benefit plans include those that are contracted-out of social security (historically, the common approach), contracted-in plans and cash balance plans. The most important funding vehicles are as follows:

- Employees' Pension Fund (EPF). Introduced in 1966, it is the traditional funding vehicle for large plans that "contract out" of the earnings-related portion of social security (EPI). In 1989, termination insurance was added.

- Tax-qualified pension plan (TQPP). Introduced in 1962, it is for "contracted-in" plans, and its use generally has been confined to small plans. This funding arrangement is being phased out, and existing plans must convert to one of the other arrangements by 31 March 2012. (TQPPs will be ignored for the balance of this analysis.)

- Contract-type corporate pension fund with a trust company, life insurer, etc...

- Fund-type corporate pension fund. A separate legal entity with the same structure as an EPF.

152. The first two are the traditional arrangements, and the last two financing vehicles were introduced under the Pension Reform Law. The new arrangements have the same funding requirements as the traditional EPFs (to be described below). However, they only can be used for contracted-in plans, and there is no insolvency insurance. Also, the tax treatment of employee contributions, investment income and benefit payments is different.

\section{Minimum Funding Requirements.}

153. Traditional minimum funding requirements were undemanding. Past service liabilities and actuarial losses could be amortized over a minimum of 7 years and a maximum of 20 years.

- In 1997, the 7-year minimum amortization period was reduced to three years.

- Also in 1997, a solvency test was introduced. If the value of accumulated assets is less than $105 \%$ of the termination liabilities of the contracted-out portion or $90 \%$ of the termination liabilities of total plan benefits, the shortfall must be eliminated within a maximum period of 7 years.

- However, if the plan is severely underfunded and the employer is in financial distress, it is possible to reduce benefits. Conditions for reducing benefits include approval by two-thirds of the plan participants and agreement of the labor union. 
- Following further downturns in the stock market, the government introduced temporary relaxations of the minimum funding requirements, including a possible two-year suspension of deficit amortizations and an extension of the 7-year maximum amortization period to 10 years.

- Prior to 1997, the discount rate for calculating liabilities was prescribed. Now, the fund can decide its discount rate. The government only implies a rate within the range of $80 \%$ to $120 \%$ of the average yield of 10-year government bonds issued during the previous five years.

\section{Customary funding practices.}

154. Actuarial valuations are performed on both an ongoing plan basis and a plan discontinuance basis. Various actuarial costing methods are allowed. However, the minimum funding tests described in the previous section are the dominant consideration.

\section{Maximum funding limits.}

155. Although somewhat academic at the present time, there is an upper limit on the funding of pension liabilities. The prescribed amount is the greater of $150 \%$ of actuarial liabilities calculated under the customary funding valuation (see previous paragraph) and $150 \%$ of the actuarial liabilities calculated using a minimum interest rate specified by the regulator. When the fund assets exceed this limit, the plan sponsor is required to reduce or suspend contributions.

\section{Frequency of actuarial valuations.}

156. Full actuarial valuations are required to be performed at least every five years.

\section{Bankruptcy of plan sponsor.}

157. Whatever the circumstances, the windup of a pension plan entails the allocation among the nonretired participants of the remaining fund assets, after deduction of the amounts necessary to pay benefits to current pensioners. In the case of a continuing employer, the remaining unfunded benefits for nonretired employees usually would be paid directly by the employer at the time of each employee's retirement or termination of employment (effectively, on a pay-as-you-go basis). In the case of an insolvent employer, there is a termination insurance program covering Employees' Pension Funds (EPFs), but it covers at most only about $30 \%$ of the contracted-in portion of EPFs and it does not cover the other types of pension funds.

\section{Termination of an overfunded plan.}

158. The entire surplus assets would be allocated among the plan participants.

\section{Who appoints the actuary?}

159. Pension funds (in the case of EPFs and Fund-Type plans) or plan sponsors make actuarial service contracts with third party actuarial service providers recognized by the regulator (the MHLW). Each of these recognized service providers must employ at least one licensed pension actuary within the company. Qualification of a pension actuary is decided by the MHLW, based on experience and capabilities. 
OECD Working Paper on Insurance and Private Pensions

\section{Role of the actuary.}

160. The licensed pension actuary performs the roles of (a) confirming the actuarial calculations performed by the pension fund or plan sponsor and (b) certifying the validity and appropriateness of the actuarial documents submitted by the pension fund or plan sponsor to the Minister. 


\section{NETHERLANDS}

\section{Supervisory Control.}

161. The Pensions and Savings Fund Act (PSW) provides the main body of pension plan legislation. The primary supervisory body is now the central bank (DNB); it supersedes the pension and insurance supervisory authority (PVK) in this role. Key regulations on funding are contained in the Financial Assessment Framework (FTK), which is scheduled for implementation on 1 January 2007.

\section{Minimum Funding Requirements (historical and current bases).}

162. Until 1999, the Dutch funding standards focused on the so-called "65-x" method, with 65 being the assumed normal retirement age and " $x$ " being the plan member's current age. The objective was to ensure full funding by age 65 , and the effect was to amortize the remaining costs over the period until age 65. The accrued and projected liabilities were, and indeed still are for the moment, calculated using a discount rate of $4 \%$ pa, with no allowance for future salary increases, employee turnover, etc... The $4 \%$ discount rate has been in effect for a very long time, including periods when interest rates were much higher (but adjustments were then possible). Except where otherwise indicated, all subsequent references to accrued liabilities in this section will imply the use of this $4 \%$, no salary increase, no employee turnover basis.

163. New legislation then outlawed the $65-\mathrm{x}$ method and introduced a new minimum funding standard. It requires the market value of the assets to equal or exceed the accrued liabilities. A ten-year transition period was established, but "full funding" would thereafter be required at all times. On the liabilities side, this meant full and immediate funding of the effects of salary increases, pension indexing and retroactive plan improvements. On the assets side, it means full and immediate correction of poor investment results. Notwithstanding the ten-year transition, the PVK began paying close attention to plans that are less than $100 \%$ funded on the above basis. The principle of full funding had been enshrined in the PSW, which reads: "A pension fund must at all times be able at any time and under all circumstances to reinsure its obligations with an insurance company".

164. The PVK then went one step further, by requiring the establishment of investment reserves in respect of equity holdings. On 30 September 2002, the PVK proposed a new and detailed set of funding requirements (with an implementation date of 1 January 2003). These requirements, which will continue in effect until the end of 2006, now will be summarized. The objective is for the market value of assets to equal or exceed the sum of the following;

- the accrued liabilities calculated using the current unit credit method (otherwise referred to as the "provision for pension liabilities" or PPL);

- a general risks reserve equal to 5\% of the PPL;

- an "investment risks reserve" or "asset buffer"; and

- a "future pension adjustment reserve" or "indexing buffer".

165. The basic funding requirement thus moved up to $105 \%$. In addition, there would be an indexing buffer and an asset buffer. For a typical plan, a required funding level of $135 \%$ of liabilities is not unusual. Highlights of the regulation include: 
- Assets must cover the 5\% general risks reserve at all times. The regulator must be informed immediately of any shortfall. A strategy must be developed within three months, and actions must be taken within twelve months to enable the asset value to be brought back up to the $105 \%$ level.

- The investment risks reserve must be sufficient fully to protect the fund in the event of equities falling $40 \%$ below the highest level of the applicable benchmark within the last 48 months or $10 \%$ below the lowest level of the benchmark within the last 12 months.

- The investment risks reserve must also include a $10 \%$ buffer on fixed income investments when market interest rates are $4 \%$, and a 5\% buffer when market interest rates are 5\%. No buffer is required if market interest rates are at or above $6 \%$.

- If the investment risks reserve requirements are not satisfied, the regulator must be informed without delay and a strategy developed within three months. Actions must be taken to enable the asset value to be brought up to the specified level within 2-8 years.

- If pension indexing is unconditional, the accrued liabilities (the PPL) must include an allowance for future indexing on accrued benefits. Although pension indexing under most Dutch pension plans is conditional on favourable fund performance, the PPL for these plans also must include an allowance for future indexing - if pensions have been systematically increased under such plans during recent years.

- "Depending upon the specific situation and financial structure of the fund, other special-purpose reserves may also be required. Thus for instance, funds that used the (65-x) system up to 1 January 2000 ... will have to form a reserve for this funding” (PVK, 30 September 2002).

\section{Minimum funding requirements (effective 1 January 2007).}

166. The Financial Assessment Framework (FTK) will replace the traditional statutory basis for valuing liabilities (4\% interest, no salary increases), assets and contributions with a market value method. The following summary is based on the FTK "Consultation Document" of 21 October 2004, together with subsequent commentary from the government and other sources. It also should be noted that the FTK covers solvency issues of both pension funds and insurance companies. The FTK combines both a "solvency test" and a periodic "continuity analysis". The former must be performed annually; the latter must be performed for the first time by 2008 (perhaps 2009) and then at regular intervals thereafter, but not necessarily annually. The role of the continuity analysis is to assess the financial position of the plan against the background of realistic long-term scenarios and related risks.

167. There are three possible methods for performing a solvency test. A "simplified method" is available (a) when the plan is simple and unambiguous, (b) the funding ratio is at least $130 \%$ and (c) the strategic asset mix involves less than $25 \%$ of the fund being invested in variable-yield securities. At the other extreme, an "internal model method" (an internal capital adequacy model) is allowed for large and sophisticated funds, but the requirements for following this route are demanding. In the absence of being able to, and choosing to, elect either the simplified method or the internal model method, a "standardized method" is applied. The rest of this summary will focus on the standardized method.

168. Under the standardized method:

- Accrued liabilities are calculated on a unit credit base, without allowance for the effects of future salary increases on accrued benefits. The DNB prescribes the discount rate(s) used to calculate the liabilities, based both on rising and falling yield curves. In the early phase of the FTK, pension 
funds may use a simplified method, based on the yields on fixed income securities of appropriate duration.

- The standard mortality table is the GBMV 1995-2000 table. Mortality improvement must be incorporated through the use of the "CBS 2050 forecast".

- "Conditional benefits", such as non-guaranteed increases to pensions-in-payment and to accrued benefits of present and former members, must be included in the liability calculations for the required funding level, but not the minimum funding level (see below for clarification).

- A solvency margin is then determined. It is a function of (a) the inflation risk (for plans with pension indexation) and the interest rate risk, (b) the equity and real estate risk, (c) the foreign exchange risk, (d) the commodity risk, (e) the credit risk and (f) the underwriting risk. The formula is complicated, but the solvency margin is basically a function of the square root of the sum of the squares or each risk, but with additional weighting for the interest rate and variableyield securities risks.

- The accrued liabilities plus the solvency margin then become the "required funding level". The DNB estimates that "the required asset-liability ratio an average pension fund will be less than $130 \% "$

- If the fund assets are less than the required funding level, then the shortfall must be addressed within 15 years; the amortization payments cannot be back-ended.

- If the fund assets are less than the "minimum funding level" of $105 \%$ of the liabilities (excluding conditional benefits and the solvency margin), the shortfall must be addressed within one year.

- The FTK's basic guideline for the reserve requirements is that: "starting with a situation of equilibrium, there is at least a $97.5 \%$ chance that a fund will have fully covered the unconditional commitments a year later".

\section{Customary funding practices.}

169. The majority of Dutch pension funds have continued to focus on the traditional $4 \%$ interest rate, no salary increase, no employee turnover method described above. However, this will all change with the introduction of the FTK on 1 January 2007. Some funds already perform actuarial funding valuations using independently explicit assumptions, i.e. a market-related discount rate and explicit allowances for future salary increases, employee turnover, early and disability retirements, etc... The Projected Unit Credit method is widely used in this context, with the calculations also being used to support pension expensing requirements. Customary actuarial practice after 1 January 2007 is difficult to assess. It is possible that the "required funding level" in the FTK will override other calculations and considerations.

\section{Maximum funding limits.}

170. Although there are differing opinions on whether it was enforced, the main historical constraint was that contributions could only be tax-deductible if the discount rate used to calculate liabilities was not less than 4\%. Full tax deductibility of future, FTK-required contributions is an important issue.

\section{Frequency of actuarial valuations.}

171. Valuations are required to be performed every year. 


\section{Bankruptcy of plan sponsor.}

172. Whether the plan is overfunded or underfunded, the entire assets of the fund are allocated between the plan members. There is no government insurance program to cover shortfalls, although regulation of ongoing plans is focused on constant avoidance of any such underfunding.

\section{Termination of an overfunded plan.}

173. The entire assets are allocated between the plan members. In other words, each plan member receives an appropriate share of the funding excess. During the 1990s, the fund assets of many plans comfortably exceeded accrued liabilities. Many employers took contribution holidays or withdrew excess assets, and the legislation was fairly accommodating in this regard. However, as already indicated, a plan sponsor cannot withdraw surplus assets from a terminated plan.

\section{Who appoints the actuary?}

174. The board of foundation that administers the plan and the fund appoints the actuary. This board generally is comprised of an equal number of employee and employer representatives.

\section{Role of the actuary.}

175. The roles of the actuary can vary from one plan and fund to another, but the primary role is to check whether assets are sufficient to cover the obligations, all in accordance with the law and the requirements of the regulator. There is some confusion over whether the plan sponsor or the board of foundation has the final say on critical issues such as funding. This has the potential to create problems for the plan actuary, who is employed by the board of foundation and works in the interests of ensuring security for the plan members. 


\section{NORWAY}

\section{Supervisory Control.}

176. The majority of the occupational Norwegian pension plans are insured, and they are regulated and supervised as far as possible in line with insurance companies. A small number of the largest plans hold around 25\% of overall pension fund assets in 'pensjonskasser', a form of independent trust regulated by the Financial Supervisory Authority. The minimum funding rules are contained in the 1988 Insurance Activity Act. The 1956 Financial Supervision Act provides for the supervision by the Financial Supervisory Authority (FSA) of financial institutions such as pension funds and insurance companies. This Act also defines the powers of the FAS and requires auditors to notify the FSA of special events (whistle-blowing). Pension funds must register with the FSA, and this registration is subject to authorization of the plan rules.

\section{Minimum Funding Requirements.}

177. Separate from the regular minimum funding requirement, each pensjonkasse must comply with a minimum capital standard defined by the Ministry of Finance. It is the same for both insurance companies and pension funds and equals $8 \%$ of the total of risk-weighted asset items and off-balance sheet items. In addition, the capital base of pension funds must exceed a certain Norwegian Krone threshold that is adjusted on a yearly basis according to changes in the Consumer Price Index. From 1998 an additional requirement was introduced that pension funds should have financial strength to be able to absorb an adverse development in the financial markets of a certain order.

178. All pension plans, whether defined contribution or defined benefit, and whether financed through insurance contracts or a pensjonkasse, must be administered on an individual allocation basis. The minimum reserves held for each plan member in a pensjonskasse should equal the value of that member's accrued benefits (but without allowance under final-salary plans for the effects of future salary increases on such accrued benefits). If the annual report reveals underfunding, or underfunding is revealed in some other way, the pension fund shall immediately take the necessary actions to regain full funding. Legislation does not, however, indicate the length of the time period within which full funding should be achieved. Deficits arising form wage increases are assumed to be spread equally over the remaining time to retirement.

179. The maximum permissible technical interest rate for calculating liabilities and contributions is $4 \%$ per annum. If the pension fund was established after 1993, the maximum technical interest rate is $3 \%$ pa. Furthermore, the maximum rate of interest is $3 \%$ for all contributions (premiums) due after 1 January 2004, even for insurance contracts and pension funds established prior to 1993, and for the technical provisions derived from these premiums. Fund assets are taken at market value.

\section{Premium Fund and Other Reserves}

180. In addition to the payment of regular premiums, and with the objective of smoothing the funding, the tax authorities allow tax-deductible payments into a so-called "Premium Fund". The annual payment to the Premium Fund cannot exceed 50\% of the average annual premium during the last three years, and the accumulated amount in the Premium Fund should not exceed six times the regular annual premium. Any excess must be refunded to the plan sponsor. The main application of the premium fund is paying future contributions, thus helping plan sponsors through difficult economic times. 
181. Legislation also allows for the accumulation of additional provisions, up to a maximum of 8 per cent of the regular mathematical reserves. Then, if the return on fund assets falls short of the interest rate for discounting liabilities, these additional provisions can be used to compensate for the shortfall and thus maintain the prescribed level of mathematical reserves.

\section{Customary funding practices.}

182. All regular actuarial calculations employ one or other of the following methods.

- Level annual premium method. Benefits are funded by charging a level annual premium over the active service period, based on current salaries. Each subsequent increase in projected benefits (arising from salary increase etc.) is charged over the subsequent future service period by further series of level annual premiums. Historically, this was the traditional method.

- Current unit method. Benefits are funded as they are accrued, again without any allowance under final-salary plans for the effects of future salary increases on such accrued benefits. Premiums for the following year reflect both the cost of purchasing an additional year of pension accrual plus, if applicable, the cost of updating past accruals to current salary levels. Effective from January 1, 2001, the current unit method replaces the level annual premium method in the majority of pension plans.

183. There are no other prescribed actuarial assumptions, but the basis of valuation for pension funds (also including mortality, disability and expenses assumptions) must be approved by the Financial Supervisory Authority. A valuation basis which is not prudent will not be approved. Generally used actuarial assumptions are as follows:

- Economic assumptions: No further assumptions are made regarding future pension increases or the effects of future salary increases. The discount rate has already been discussed.

- Demographic assumptions: The demographic assumptions used in all calculations are usually chosen according to standard tables. The assumptions have to be approved by the supervisory authority. The standard tables currently being used are the IR73 tables (disability) and K63 tables (old age and death).

- Allowance for expenses. A separate allowance normally is made for the administration expenses associated with operating the pension plan and fund.

\section{Maximum funding limits.}

184. No maximum funding rules apply.

\section{Frequency of actuarial valuations.}

185. Pension funds must submit annually to the FSA a standard report prepared by the appointed actuary. The contents of this report must conform to the guidelines set down by the supervisory authorities. Funds must also produce a report proving compliance with the capital standard requirement and providing certain statistics on their operations. The Financial Supervisory Authority recommends that an actuarial valuation is performed more frequently, at least semi-annually. 


\section{Bankruptcy of plan sponsor.}

186. There is no requirement to insure against financial loss, and no compensation fund exists. In the case of bankruptcy of the plan sponsor when the fund has insufficient assets, the fund (and, thus, the plan members) will normally be among the creditors in the legal sense and its claims will be handled by the court as a part of the overall bankruptcy treatment. The fund itself, being a separate legal entity, is protected from creditors. It should be noted that there have not yet been any cases of a bankrupt plan sponsor with an underfunded plan, presumably due to the stringent funding requirements.

\section{Termination of an overfunded plan.}

187. Detailed legal rules govern the conditions under which a plan may be wound up and the resultant allocation of plan assets. When a terminated plan is overfunded, the surplus assets normally are applied to enhance members' benefits.

\section{Who appoints the actuary?}

188. All institutions administering pension plans must appoint an auditor and an actuary. The actuary is appointed by the board of the pension fund, but he/she must be explicitly approved by the FSA.

\section{Role of the actuary.}

189. The roles, duties and rights of actuaries are laid down in the law. The calculations performed by actuaries for self-administered pension funds include:

- calculation of the pension fund's contingency reserve;

- calculation of the premium rates (tariffs) and resultant pension plan contributions;

- calculations for accounting purposes;

- calculation of the value of the pension rights when an employer or group of employees terminates the pension contract;

- calculation of transfer values in the case of bulk transfers arising from company takeovers or mergers. 


\section{PORTUGAL}

\section{Supervisory Control.}

190. Occupational pension plans are supervised by the insurance supervisory authority, o Instituto de Seguros de Portugal (ISP). Pension funds assets must be held and managed by a pension fund manager, which can be either an insurance company or a pension fund management company. The primary legislation governing the operation of pension plans and funds is Decree Law $n^{\circ} 475 / 99$ of 9 November 1999.

\section{Minimum Funding Requirements.}

191. Minimum funding requirements are established by the ISP. The basic objective of the minimum funding standards is for the assets to exceed the accrued liabilities. For these purposes:

- Assets are taken at fair market value.

- Accrued liabilities are equal to the sum of (a) the present value of accrued liabilities of non-retired members, calculated using the current unit credit method without salary projection, and (b) the present value of pensions-in-payment to retirees and other beneficiaries.

- Pensions of non-retired members are assumed to commence at normal retirement age, although an adjustment must be made for plans that provide subsidized early retirement benefits.

- The TV 73/77 mortality table must be used.

- The discount rate is $4 \frac{1}{2} \%$ pa.

- No assumptions are permitted regarding disability or employee turnover,

- If indexing of pensions is contractually guaranteed, then an allowance for the effect of future indexing must be included in the calculation of the accrued liabilities.

192. In the event the fund assets are less than the value of pensions already in payment, the pension fund manager shall instruct the plan sponsor to contribute the necessary funds. The pension fund manager must issue this notice within 15 days of verifying that there are insufficient assets, and the plan sponsor then has 180 days following the notice in which to make the necessary contributions. If the contributions are not made, the fund shall be wound up. Furthermore, the pension fund manager may only pay new pensions under the plan if the fund assets are equal to or exceed the present value of both the pensions currently in payment and the new pensions due - calculated according to assumptions set out in the minimum funding regulations. This constraint does not apply when a funding program already has been approved by the ISP.

193. In the event the fund assets are less than the total accrued liabilities, and the shortfall is not immediately addressed through additional contributions, the pension fund manager shall propose the correction of this situation to the plan sponsor. If no suitable funding plan has been drawn up within one year, the pension fund manager should wind up the fund in accordance with procedures laid down by the ISP. 


\section{Customary funding practices.}

194. Customary funding practices are established by legislation, the actuarial profession and the ISP. It is established practice that the interest rate used in the calculations should be chosen in a prudent way, taking into account any adverse fluctuations. Additional constraints apply to pension plans in the banking sector, where the law specifies maximum permissible spreads between the discount rate and the salary and indexing assumptions. Otherwise, the following observations can be made:

- The most common actuarial funding methods are Projected Unit Credit and Attained Age.

- It is normal to use the same mortality table for females and males.

- The appointed actuary establishes the economic and demographic assumptions, taken into account the general ISP rules.

- The minimum funding requirement is a funding constraint, rather than a funding objective.

- Fund assets are taken at market value.

- Amortization periods for unfunded liabilities and experience deficiencies are to be agreed with the ISP. Regulations only establish a maximum amortization period of 20 years for unfunded liabilities at plan inception, but most amortization periods do not exceed 10-15 years. The funding requirements for the banking sector are strict and more prescriptive.

- In the event of a shortfall due to plan improvements or experience losses, the appointed actuary proposes the amortization period. This will be analyzed by the ISP on a case-by-case basis and usually varies between 3 and 10 years.

- Disability and death-in-service benefits may be insured, in which case the annual insurance premium will be added to the current service cost for the retirement benefits. Even if these benefits are not (re)insured, the actuary may still cost them on an annual "risk premium" basis.

\section{Maximum funding limits.}

195. There are no direct limits on the maximum amount of assets that can be held in a pension fund, but there are limits on employer contributions for tax purposes. Employer contributions to plans that do not provide pre-retirement vesting are only tax deductible up to a limit of $15 \%$ of annual payroll (25\% if the employees are not covered by social security). Employer contributions to plans that do provide preretirement vesting are fully tax deductible. In an overfunding situation, the plan sponsor can reduce or suspend contributions. A plan sponsor can request prior approval for a return of surplus, which will only be possible if the surplus exists for structural reasons over five consecutive years and annually exceeds a set percentage of the accrued liabilities, whilst maintaining a minimum funding percentage in accordance with ISP regulations.

\section{Frequency of actuarial valuations.}

196. Valuations are required to be performed at least every three years, but in practice are performed annually. 


\section{Bankruptcy of plan sponsor.}

197. In the event of the bankruptcy of the plan sponsor and the subsequent termination of an underfunded plan, the fund assets are allocated among the plan members in accordance with a set of priorities defined in law. They are:

- Members' individual accounts (under contributory plans);

- Pensions-in-payment;

- Pensions for members of an age equal to or greater than normal retirement age;

- Vested rights of members existing at the time of the plan wind-up;

- Accrued pensions not covered by the previous paragraphs;

- Contractual indexing of pensions-in-payment.

\section{Termination of an overfunded plan.}

198. Once all vested and non-vested accrued benefits have been guaranteed, the allocation of any excess assets is decided jointly between the pension fund manager and the plan sponsor and requires prior approval from the ISP. Whenever the excess assets result from a drastic reduction in the number of nonvested plan members, such assets first shall be used to guarantee accrued pensions for such ex-members. If it is decided that surplus assets are to revert to the plan sponsor, a special tax will be applied unless the plan sponsors proves that the surplus is due to a cessation of labor contracts, previously accepted by the Directorate General of Taxation.

\section{Who appoints the actuary?}

199. The pension fund manager shall appoint an appointed actuary for each defined benefit or hybrid pension plan when submitting an application to incorporate a closed pension fund or add a new group of members to an existing open pension fund. The appointed actuary shall be chosen from a list of approved actuaries who comply with the conditions laid down by the ISP.

\section{Role of the actuary.}

200. In addition to preparing the annual actuarial report, the appointed actuary is required to verify:

- the actuarial calculations and the pension plan's funding level;

- the suitability of the technical and actuarial funding plan;

- the present value of the total liabilities (for the purposes of determining whether there is any funding excess); and

- the suitability of the nature of the fund assets in relation to the pension plan liabilities (an assessment required periodically by the ISP and in accordance with its regulations).

201. The duties of the appointed actuary are described in more detail in Regulation 06/2004-R. 


\section{SPAIN}

\section{Supervisory Control.}

202. Occupational pension plans are supervised by the General Directorate of Insurance and Pension Funds, which is part of the Ministry of Economy.

\section{Regulatory Framework.}

203. Royal Decree 1/2002 consolidates the Pension Plan and Pension Funds Law of 1987 (Ley de Planes y Fondos de Pensiones ) and all its modifications. It regulates the establishment of pension plans, pension funds and pension fund management entities, defines maximum contribution limits and includes measures concerning protection of rights. These issues have been further developed by the Royal Decree 304/2004 that endorses the Pension Plans and Pension Funds Regulations and repeals the prior Royal Decree 1307/1988. The 1999 Royal Decree on the implementation of employers' pension agreements with employees and beneficiaries (Reglamento sobre la instrumentación de los compromisos por pensiones de las empresas con los trabajadores y beneficiarios), based on the Insurance Law of 1995 (Ley de Ordenación y Supervisión de los Seguros Privados), requires plan sponsors to implement occupational pension agreements through group insurance contracts and/or the creation of a pension fund. The decree also restricts the establishment of book reserves to certain occupational pension agreements in the financial sector and provides for transitional arrangements for pre-existing plans.

\section{Statutory Funding Requirements.}

204. Pension plans must follow an actuarially recognized capitalization funding method. The funding must be on an individual, fully allocated basis. Funding requirements include the following:

- Assets must be sufficient to cover the accumulated benefit obligation.

- The valuation methods for fund assets differ by asset class. With some exceptions, assets are taken at their fair or market value.

- A minimum solvency margin requirement applies. It is $4 \%$ of actuarial liabilities in the case of defined benefit plans and $4 \%$ of accumulated contributions in the case of defined contribution plans that provide a guaranteed rate of return. There is also an additional requirement of $0.3 \%$ of death and disability lump sums. There is a minimum, overall solvency margin.

- The two actuarial costing methods approved by the $21^{\text {st }}$ July 1990 regulation are the Individual Entry Age method and the Projected Unit Credit method. The latter has been the most commonly adopted, but other methods are now growing in popularity.

- The maximum discount rate for calculating liabilities is $4 \%$ per annum. Other economic assumptions affecting the benefits (e.g. salary inflation, price inflation) should be appropriate when considered in conjunction with the choice of discount rate.

- The mortality and morbidity tables must be based on local or foreign experience that is no more than 20 years old at the valuation date and projected using recognized actuarial techniques. For plans existing on 1 November 2000, the generation tables PERM/F -2000 C is recommended, with 
the possibility of a ten year transition to its full adoption. For new plans, PERM/F $2000 \mathrm{P}$ tables are acceptable. It should also be possible to use GRM/F-95 tables. Another alternative is to use tables that are based on the actual experience of the pension plan population; strict conditions are imposed.

205. The time period over which shortfalls must be corrected is not currently specified, although new rules are expected to be issued on this matter in the near future.

\section{Maximum funding limits.}

206. No maximum funding rules apply. In the case of an overfunded position, the plan rules specify how the excess assets will be allocated. The current practice is to reduce the plan sponsor's contributions or to increase the members' benefits.

\section{Frequency of actuarial valuations.}

207. Actuarial valuations are required every three years from all defined benefit plans and from defined contribution plans that provide a guaranteed rate of return. However, those plans that require a solvency margin to be set aside (basically, all non-insured plans) must perform annual valuations.

\section{Bankruptcy of plan sponsor.}

208. In the case of the bankruptcy of the plan sponsor, the plan members have the right to their accrued vested benefits. In case of a defined benefit plan, the vested right will be adjusted and reduced depending on the existing "Technical Provision and the Solvency Margin" at the time of the bankruptcy of the plan sponsor. Insolvency insurance protection is not required, and no compensation fund exists.

\section{Termination of an overfunded plan.}

209. If a plan is terminated with surplus funds, these will be distributed to the plan members and beneficiaries in proportion to their vested rights. The same rules apply whether the plan is terminated as a result of the sponsoring employer ceases its activities or the plan's approval is revoked. Under certain circumstances, the General Directorate of Insurance and Pension Funds may take part in the winding up of a plan and/or a fund, in order to ensure the protection of rights.

\section{Who appoints the actuary?}

210. The actuary is appointed by the Control Commission of the pension plan. The actuary must be independent and comply with legally established professional requirements. The regulator currently does not maintain a register of approved actuaries, so regulation is through the actuarial association.

\section{Role of the actuary}

211. The roles of the actuary include recommendations concerning assumptions, the resultant valuation of the pension plans' liabilities and funded ratio, and contribution requirements. 


\section{SWITZERLAND}

\section{Supervisory Control.}

212. Each canton designates an authority that supervises the pension institutions headquartered in that canton. The federal government directly supervises pension institutions that have a national or international character, as well as certain other pension institutions such as those of the federal government and the national bank. The federal social insurance office oversees the 26 cantonal supervisory authorities.

213. Switzerland has extensive legislation concerning the design and operation of pension plans. The first focus of this legislation is on the mandatory benefits, whereby all employers must provide second pillar pensions for their employees. The minimum contributions are age-related and cover a specific slice of salary. The interest rate credited to such contributions is set by the government; it was $4 \%$ pa for many years, but has since fluctuated (reaching a low of $2.25 \%$ in 2004). The annuity conversion rate is also specified. It also has been changed in recent years, as a result both of declining interest rates and increased longevity. Mandatory death and disability benefits are also specified. In summary, mandatory pension plans are classified as defined benefit plans for actuarial purposes, and they do indeed require the preparation and submission of actuarial valuation reports. The legislation on mandatory pension is known as BVG in German and LPP in French. Many employers sponsor defined benefit or defined contribution pension plans providing higher benefits than those required under the mandatory pension legislation. It is then necessary to maintain BVG/LPP shadow accounts, to ensure that each member receives at least the mandatory benefit (whether on death, disability or retirement).

\section{Minimum Funding Requirements.}

214. The main funding requirements are documented in the 1984 Ordinance BVV2/OPP2, as subsequently amended. Prior to 2005, pension funds were required to fully fund their liabilities at all times, but new regulations now allow plans to be underfunded for a limited time. Highlights of the new regulations are:

- For the purposes of determining the funded position, the liabilities must include the asset fluctuation reserves. The assets must exclude any employer contribution reserve (see below), unless the employer has renounced the use of such reserves.

- Subject to guidance from the appointed actuary, the pension fund sets the method for determining its technical reserves and its asset fluctuation reserves. The methodology cannot subsequently be changed without good reason.

- Whatever the degree of underfunding, the supervisory authority must immediately be notified of the size of the deficit and explain how the deficit arose.

- In normal situations, a funded ratio of at least $90 \%$ is deemed not to present serious problems and not to require immediate remedial action.

- In contrast, a funded ratio of less than $90 \%$ is deemed to be "important", and a program to eliminate the underfunding must be established. An amortization period of 5-7 years would generally be deemed reasonable. An amortization period exceeding ten years is not allowed. 
- Such special "recapitalization contributions", whether paid entirely by the employer or by both the employer and the employees, will not vest when the employee subsequently leaves the plan.

- In the case of serious underfunding, and if the plan rules allow, more drastic measures can now be contemplated. Such potential actions can include reduction or elimination of interest credits and reduction of future benefit accruals.

- In the case of serious underfunding of a plan with a large proportion of pensioners, temporary contributions from the pensioners themselves also can be required. Understandably, the conditions for taking such drastic actions are strict.

\section{Customary funding practices.}

215. The actuary works with the plan sponsor to develop a sound funding program. The traditional approach to calculating accrued and projected liabilities involved using a discount rate of around 3.5\%$4.5 \%$, with no allowance for the effects of future salary increases, no employee turnover assumptions, etc... However, many plans now use explicit assumptions concerning interest rates, future salary growth, employee turnover, early retirement and disability decrements, etc... There are various approaches to the valuation of the fund assets.

216. The regulator is primarily concerned that the employer contribution rate will be sufficient, together with future employee contributions and existing fund assets, to fund all the prospective obligations. In some defined benefit plans, the employer's contribution rate is set in the plan rules or is constrained in some other fashion. Overfunding is then defined as the excess of the fund assets and the present value of future contributions over the projected liabilities. Thus, two different plans with identical fund assets and accrued liabilities can be deemed overfunded or underfunded depending solely on the prescribed (or otherwise established) levels of their future contributions. A plan deemed underfunded on this basis can still have fund assets that exceed the accrued liabilities, and vice versa.

217. It should also be noted that the plan sponsor cannot contribute less than the employees. This is a cumulative test. If the plan maintains an "employer contribution reserve" that is credited with employer contributions in excess of employee contributions, then any credit in the reserve can be used in subsequent years to reduce employer contributions below the level of employee contributions.

\section{Maximum funding limits.}

218. There are no direct limits on maximum funding. However, there are now upper limits on the benefits that can be provided under pension plans and the contributions that can be made to such plans. There is also now a maximum on the annual salary that can be recognized for pension purposes, although the limit is high (SFr 744,000 in 2005). The Swiss tax authorities can withdraw tax exemption from contributions to overfunded plans, but there is a certain margin before considering a plan as overfunded for these purposes. Anyway, given that it is impossible to return any funding excess to the plan sponsor, overfunding is not a sound philosophy for most employers.

\section{Frequency of actuarial valuations.}

219. Valuations are usually performed every three years, although larger plans may conduct annual valuations. Pension expensing requirements are also pushing plan sponsors towards annual valuations. 


\section{Bankruptcy of plan sponsor.}

220. Whether the plan is overfunded or underfunded, the entire assets of the fund are allocated between the plan members. There is a guarantee fund which covers any shortfalls in case of sponsor or pension fund bankruptcy, but with an upper limit on the insured benefits payable to an individual plan member.

\section{Termination of an overfunded plan.}

221. The entire assets are allocated between the plan members. In other words, each plan member receives an appropriate share of the funding excess. As already indicated, there are no circumstances under which excess assets can revert to the plan sponsor.

\section{Who appoints the actuary?}

222. The board of foundation appoints the actuary. However, unless constrained by the plan rules, funding decisions are within the control of the plan sponsor. In this important regard, one can say that the actuary also works for the plan sponsor.

\section{Role of the actuary.}

223. The primary roles of actuary are (a) to advise on future funding requirements and (b) to certify to the regulator that plan's funding is sufficient to meet its obligations. 


\section{UNITED KINGDOM}

\section{Supervisory Control.}

224. As a result of changes introduced by the Pensions Act 2004, a new pension regulatory authority named "The Pensions Regulator" (TPR) has been created. It has more powers than the Occupational Pensions Regulatory Authority (OPRA) which it replaced.

\section{Important developments in 2004-2005.}

225. The Pensions Act 2004 also introduced the concept of a new funding standard to replace the Minimum Funding Requirement (MFR). Implementation of the new standard (summarized below) was twice delayed, but eventually came into force on 30 December 2005. The final "Regulatory Code of Practice" $\left(n^{\circ} 3\right)$ then was issued by TPR and became effective on 15 February 2006. As there is an inevitable transition period from the MFR to the new "Statutory Funding Objective", and because the MFR provides some interesting lessons for everyone, descriptions of both approaches are provided.

\section{Trustee/plan sponsor agreement under the new funding legislation.}

226. The trustees are responsible for the overall management of the valuation process, although the trustees normally must reach agreement with the plan sponsor on certain key funding matters. The legislation requiring the employer's agreement is modified where the plan rules give someone other than the employer the power to determine the contribution rate, as follows:

- If the trustees have the power, unrestrained by conditions, to determine the contribution rate and no other person has the power to reduce or suspend contributions - the trustees are required to consult the plan sponsor but the plan sponsor's agreement is not required.

- If the trustees have the power, subject to certain conditions, to determine the contribution rate and no other person has the power to reduce or suspend contributions - and if such conditions are satisfied - the trustees are required to consult the plan sponsor but the plan sponsor's agreement is not required.

- If the contribution rate is determined by, or on the advice of, a person other than the trustees or the plan sponsor (usually the actuary) - the trustees must obtain the plan sponsor's agreement. They must take into account the recommendations of the other person on the method and assumptions for calculating the technical provisions and on the preparation of any recovery plan.

\section{New Funding Legislation.}

227. Part 3 of the Pensions Act 2004 requires every occupational pension plan to adopt a "Statutory Funding Objective" aimed at ensuring that the plan has "sufficient and appropriate assets to cover its technical provisions". Highlights of this legislation include:

- The trustees are required to set out the funding principles in a document to be made available to the plan members. The document should identify the statutory funding objective and a policy on how to eliminate any funding deficit, including the period over which this is to be achieved. 
- Under the MFR legislation, the old regulator (OPRA) had the power to extend the period for funding a deficit. There is no comparable provision under the new legislation.

- The regulations do not prescribe the actuarial valuation assumptions to be used. Similarly, the regulations do not prescribe the actuarial cost method, although it must be an accrued benefits funding method (projected unit credit, partially projected unit credit, current unit credit or discontinuance basis). "It is for the trustees to determine which method and assumptions are to be used in calculating the scheme's technical provisions. This is another matter on which they must take advice from their actuary and reach agreement with the employer."

- The individual economic and actuarial assumptions should be chosen prudently. The trustee must consider whether, and to what extent, account should be taken of a margin for adverse deviation. However, the legislation doe not require technical provisions to be set so conservatively as to match the level needed to buy out the accrued liabilities from an insurance company.

- The trustees should aim for any funding shortfall to be eliminated as quickly as the plan sponsor can reasonably afford. In preparing a recovery plan to address a funding shortfall, the trustees (in consultation with the plan sponsor) also must take into account the asset and liability structure of the plan, its risk profile, its liquidity requirements and the age profile of the members.

- If the trustees cannot obtain the agreement of the plan sponsor on one or more funding matters (most specifically, contribution increases), the trustees - with the employer's agreement - can reduce or otherwise modify the plan's future benefit accruals.

\section{Previous Minimum Funding Requirements (MFR).}

228. The basic objective of the existing "Minimum Funding Requirement" (MFR) is that fund assets should be sufficient to cover, in the event of plan termination:

(a) for pensioners, the purchase of insurance company annuities; and

(b) for those who have not retired, the payment of an amount which, on transfer to another pension arrangement, would give individuals a reasonable expectation of receiving their plan retirement pension.

229. The actuarial assumptions to be used are prescribed in considerable detail. The calculations are complex, and there have been many criticisms of the MFR in recent years. Although the government intends to abolish the MFR, it is worth reviewing the standard in order to learn lessons for the future and for other countries.

230. For these MFR purposes:

- Assets are taken at realizable market value.

- The accrued liabilities are valued using the current unit credit method.

- Accrued benefits for active employees are calculated on the assumption of immediate termination of employment (accrued, vested rights).

- There are complicated rules on the "MFR pension age", i.e. the age at which pension payments are assumed to commence. 
- If partial cash commutation is permitted at retirement, then the calculations should assume the member exercises this option to the maximum allowed.

- Allowance must be made for discretionary benefits already granted (e.g. ad hoc pension indexing), but there must not be any allowance for future discretionary benefits.

- The discount rate for valuing pensions-in-payment is the prevailing market yield on UK government securities (gilts), However, pensioner liabilities in excess of $£ 100$ million may be valued using the assumed long term return for UK equities (plus the market value adjustment factor - see below).

- For the period up to retirement, the discount rate for valuing the pension rights of members who have not yet retired is broadly the assumed long-term return on equities. For the ten years up to MFR pension age, the discount rate gradually moves from the equity return to the gilt return. For the period after retirement, the discount rate is the assumed long-term return on gilts. A "market value adjustment" factor then is applied to the resultant liabilities, to reflect prevailing UK equity dividend yields. This market value adjustment factor in relation to equities is the ratio of $3.00 \%$ to the current dividend yield on the FTSE Actuaries All-Share Index.

- Pre-retirement and post-retirement mortality is generally to be determined in accordance with the PA(90) standard mortality table, rated down two years..

- Other assumptions are prescribed in some detail.

- There should be an allowance for termination expenses. The formula is prescribed.

231. In the event of a shortfall (assets less than accrued liabilities), additional contributions must be made to the fund such that:

- the fund assets reach at least $90 \%$ of the MFR level within three years (formerly, one year).

- the fund assets reach at least $100 \%$ of the MFR level within ten years (formerly, five years).

232. The plan actuary, as part of the regular valuation (see below), also is required to make a statement regarding the adequacy of the fund assets to meet its liabilities if the plan were to be discontinued. This should not be confused with the MFR.

\section{Customary funding practices.}

233. There are no government constraints in this area. The actuary works in accordance with the requirements of his profession. In particular, generally accepted valuation methods for pension plan actuarial valuations are set out in "Actuarial Guidance Note GN26".

- Pension plan liabilities are generally calculated on the assumption that the plan is ongoing.

- The most common actuarial valuation method is now Projected Unit Credit, prompted in large part by the accounting standards for pension costs in company accounts. Historically, the objective has been a stable future funding rate, in the form of a level percentage of salary. Thus, Aggregate, Attained Age and Entry Age methods were more common, and they are still sometimes used. The minimum funding standard uses the Current Unit method and the maximum funding method uses the Projected Unit Credit method. 
- The method of calculating the actuarial liability for pensions-in-payment and deferred pensions is common to all the funding methods.

- There must be an explicit allowance for future expenses that are a responsibility of the fund.

- The actuary establishes the economic and demographic assumptions in accordance with standard actuarial practices and unconstrained by government regulations.

- Disability and death-in-service benefits may be insured, in which case the annual insurance premium will be added to the current service cost for the retirement benefits. Even if these benefits are not insured or reinsured, the actuary may still cost them on an annual "risk premium" basis. In this regard, it is important to understand that most UK pension plans provide large lump sum death-in-service benefits that are not a function of accrued pensionable service.

- The MFR was deemed to be a funding constraint, rather than a funding objective. Clearly, the maximum funding limitation also is a funding constraint.

- Fund assets are now usually taken at market value, although other approaches are still used.

- These valuations serve as the basis for claiming employer tax deductions.

\section{Maximum funding limits.}

234. The Inland Revenue (tax authorities) imposes strict limits on the maximum amount of assets that can be held in a pension fund without the loss of tax advantages. In simple terms, the assets should not exceed $105 \%$ of the accrued liabilities (as calculated under the projected unit credit method). The key actuarial assumptions are prescribed. In the event of assets exceeding the maximum, there are a number of choices available:

- all or part of the excess can be used to reduce or suspend employee or employer contributions during the next five years;

- all or part of the excess can be used to fund retroactive plan improvements;

- any excess still remaining must be withdrawn from the fund (special taxes apply).

235. The whole issue of maximum funding limits is under review.

\section{Frequency of actuarial valuations.}

236. Valuations are generally required to be performed every three years. Under the new regulations, formal actuarial valuations still must be performed at least every three years; however, in the absence of annual valuations, the actuary will be required to produce interim annual actuarial reports.

\section{Bankruptcy of plan sponsor.}

237. Under the Pensions Act 2004, and in the event of the bankruptcy of the plan sponsor, the pension fund has the status of an unsecured creditor. Associated parties, such as the UK or non-UK parent company, are required to help fund any deficit, whether on bankruptcy of the plan sponsor or conventional plan termination by a solvent plan sponsor. Any shortfall on plan termination by a not-insolvent plan sponsor will be treated as statutory debt, and the shortfall will be calculated based on the cost of securing 
indexed immediate and deferred annuities from an insurance company. A government compensation fund, the Pension Protection Fund (PPF) also was introduced as part of the 2004 pension reform.

\section{Termination of an overfunded plan.}

238. The plan rules govern the application of excess assets arising in the event of a plan termination. If allowed by these plan rules, excess assets can be refunded to the plan sponsor; in which case, a special tax will be applied.

\section{Who appoints the actuary?}

239. The UK equivalent of the "pension entity" in OECD parlance is the board of trustees. The trustees appoint the plan actuary.

\section{Role of the actuary.}

240. The roles of the actuary are (a) to assess the funding level and advise on the contributions needed to achieve and maintain the desired level, (b) to make a statement regarding the MFR, (c) to make a statement regarding the plan's ability to meet plan termination liabilities, (d) to provide a contracting out certificate, where required, (e) to make calculations required for the plan sponsor's commercial accounts, and (f) to provide a statement to the tax authorities regarding the $105 \%$ limit. Typically, the plan sponsor and the trustees agree on the employer's future funding rate, based on the advice of the actuary.

241. The roles of the actuary in regard to the new statutory funding objective include confirmation that the agreed contributions are sufficient to enable the statutory funding objective to be met, or to continue to be met, by the end of the recovery period.

242. Pursuant to the requirements of Section 230(1) of the Pensions Act 2004, the Faculty and Institute of Actuaries issued a new guidance note (GN 49) on "occupational pension schemes - scheme funding matters on which the advice of an actuary must be obtained". It also revised guidance note GN 9 on "funding defined benefits - presentation of actuarial advice". Both guidance notes became effective on 30 December 2005. 


\section{UNITED STATES}

\section{Supervisory Control.}

243. Funding requirements are enforced by the Internal Revenue Service (IRS), which is part of the U.S. Department of the Treasury. The minimum funding requirements are established under identical provisions in the Internal Revenue Code (IRC) and the Employee Retirement Income Security Act of 1974 (ERISA). Maximum deductible funding constraints are established in the IRC. Customary funding practices are established by the actuarial profession, but are constrained by the minimum and maximum funding limits.

244. The legislation governing pension plan funding is long and complex. At first glance, it would also appear to be very prescriptive, but there are still some important areas where the actuary has control over the all-important aspects of choosing the actuarial funding method and actuarial assumptions. Given the massive detail in the U.S. legislation, this summary will serve only to highlight the key points and issues.

\section{Pension Funding Reform.}

245. Various proposals have been introduced in Congress and by the Bush administration regarding improving the funding position of occupational defined benefit pension plans. Themes running through most of the proposals include:

- Funding deficits would have to be amortized over much shorter periods of time, e.g. 7 years.

- With certain exceptions, severely underfunded plans would not be allowed to make plan improvements or otherwise increase benefits. In the same vein, lump sum payments from severely underfunded active plans (and generally underfunded plans of bankrupt employers) would be strictly limited. The underlying objective of these restrictions is to avoid further aggravating the already severe underfunding of such plans.

- Future benefit accruals would be frozen under seriously underfunded plans, e.g. plans with a funded ratio of less than $60 \%$.

- "Shut-Down" benefits would be prohibited. These are payments that some pension plans make to long service employees when a plant is shut down. These benefits are typically negotiated between employers and trade unions, and they are generally unfunded. Similarly, other contingent-event benefits would be prohibited.

- The maximum funding limit would be relaxed, and plan sponsors would be allowed to make additional contributions during favourable economic times; e.g. the deductible limit could increase to (a) 150\%-180\% of the funding target, plus (b) the target normal cost, less (c) the plan's assets. However, the problem remains that plan sponsors have unattractive choices (e.g. special excise taxes) when trying to access any subsequent overfunding.

- "Funding target" is the new phrase that is equivalent to the "current liability" found in existing legislation and described below. The mortality table would be specified. There is considerable ongoing discussion concerning the most appropriate discount rate(s) for calculating such liabilities. 


\section{Minimum Funding Requirements.}

246. The current minimum funding requirements need to be understood in two parts. The first requirement, which was part of the original 1974 ERISA legislation, requires the establishment of a "Funding Standard Account". In simple terms, ignoring the complexities of interest credits and debits, the Funding Standard Account now requires the accumulated payment of at least the following:

- the normal costs (i.e. the current service cost under the plan's funding method);

- amortization over 40 years of the initial unfunded past service liability for plans in existence on 1 January 1974;

- amortization over 30 years of the cost of plan improvements and of the initial past service liability for plans that were not in existence on 1 January 1974 (even longer amortization periods can apply to some multi-employer plans);

- amortization over 10 years of the effects of changes in actuarial assumptions; and

- amortization over 5 years of experience gains and losses.

247. For these purposes:

- all the above costs "shall be determined under the funding method used by the actuary to calculate funding costs"; there are few constraints.

- the value of plan assets "shall be determined on the basis of any reasonable actuarial method of valuation that takes into account fair market value and which is permitted under regulations", i.e. fair market value or smoothed market value.

- References to "accrued liability", as opposed to the "current liability" described below, mean the accrued liabilities calculated under the method and assumptions chosen for these calculations.

248. As can readily be appreciated, a pension plan comfortably could comply with the above minimum funding requirements and yet still maintain a very poor ratio of plan assets to accrued liabilities. A second, more conventional minimum funding requirement then was introduced, and it does indeed focus on accrued liabilities and accumulated assets. For these purposes:

- The assets are to be taken at actuarial value, which may be fair market value or smoothed market value.

- The "current liability" is the value of accrued benefits - calculated under prescribed mortality tables and discount rate, and with ongoing plan assumptions as to retirement rates, turnover, etc;

- The discount rate for calculating liabilities is prescribed. It was equal to the four-year weighted average yield on 30-year Treasury bonds, and the actuary then could calculate the current liability using a rate in the range of $90 \%-105 \%$ of this rate. The $105 \%$ was temporarily relaxed to $120 \%$, as Treasury bond yields had been at historic lows relative to conservative long-term corporate bond rates, and the basis was artificially inflating the calculation of the current liability. The whole basis currently is being reviewed. 
249. If the unfunded current liability is less than $10 \%$ (i.e. the ratio of assets to current liability is at least $90 \%$ ), the plan sponsor is not required to make any supplemental contributions. [There is also a temporary relaxation in this area - if the funded ratio is at least $80 \%$ and two consecutive of the previous three years' ratio were at least $90 \%$, then no action is required]. If the ratio is less than $90 \%$, then a supplemental contribution must be made to bring the otherwise required contributions up to the "amortization percentage" of the unfunded current liability. The "amortization percentage" is $30 \%$ for funded ratios below $60 \%$, and for funded ratios above $60 \%$ it is $30 \%$ less 0.40 times the excess over $60 \%$ (e.g. a funded ratio of $75 \%$ means an amortization percentage of $24 \%$ ) - complicated, but logical. These minimum funding requirements cut off when the plan assets reach the "full funding limitation"; see below.

\section{Customary funding practices.}

250. All regularly acceptable actuarial funding methods are allowed, but the Projected Unit Credit method is dominant, especially among large plans. However, the method and assumptions need to be chosen very carefully, as they impact both the Funding Standard Account and the Maximum Funding Limit (see below). In the event that the selected actuarial funding method does not produce a value for accrued liabilities, then this value must separately be calculated under the Entry Age Normal method.

\section{Maximum funding limits.}

251. The "full funding limitation" is the greater of $90 \%$ of the current liability and $100 \%$ of the accrued liability. Assets are taken at the lesser of the smoothed market value (if such smoothing is used for minimum funding purposes) and the fair market value. In general, a plan sponsor cannot make contributions, or at least cannot make immediately tax-deductible contributions, when the full funding limitation is reached. In addition to the loss of a tax deduction, special excise taxes are payable on some contributions in excess of the maximum tax deductible contribution.

252. In the years prior to 2004, the full funding limitation was equal to the higher of (a) $90 \%$ of the plan's current liability and (b) the lower of (i) $100 \%$ of the accrued liability and $150 \%-170 \%$ of the current liability. The measure of $150 \%-170 \%$ (depending on the year) was then dropped, but alternative forms of this measure are re-appearing in proposed 2005 pension reform.

\section{Frequency of actuarial valuations.}

253. Valuations are required to be performed every year.

\section{Bankruptcy of plan sponsor.}

254. In the event of the bankruptcy of the plan sponsor and an underfunding in the pension plan, the plan may continue. However, if the plan meets the conditions for termination, the Pension Benefit Guaranty Corporation (PBGC) steps in and pays benefits up to certain guarantee limits. Plan sponsors pay annual premiums to the PBGC, based on the number of plan members and the size of the unfunded liability. The PBGC has become severely underfunded in recent years, although opinions differ widely as to the extent of the problem. Various proposals for increasing PBGC premiums and taking other measures to increase the financial solvency of the PBGC are actively under discussion.

\section{Termination of an overfunded plan.}

255. Upon termination of a plan, the plan sponsor must purchase annuity contracts in the private insurance market (or make lump sum payments if the participant and the participant's spouse agree). Surplus assets can revert to the plan sponsor. However, plan sponsors that terminate overfunded defined benefit plans are subject to an excise tax penalty of up to $50 \%$ of the excess (20\% under certain limited 
conditions). In addition, the proceeds are taxable income to the plan sponsor, and thus subject to corporate income taxes. In effect, the plan sponsor must take all necessary steps to avoid overfunding - now and in the future. Theses rules strongly discourage conservative funding, as the plan sponsor has no effective way to recoup excess assets if future investment returns and other plan experience are more favorable than expectations.

\section{Who appoints the actuary?}

256. The plan administrator appoints the actuary.

\section{Role of the actuary.}

257. In contrast to most other countries, the actuary may be a fiduciary - with all the associated additional responsibilities. The roles and responsibilities of the actuary are prescribed in some detail. 